Persp. Teol. 32 (2000) 329-362

\title{
A ORIGEM DOS PRESBÍTEROS-EPÍSCOPOS NA IGREJA DO NOVO TESTAMENTO (I)
}

\author{
Antonio José de Almeida \\ "Se se observa uma coisa na sua evolução desde \\ a origem, poder-se-á ter a visão melhor" \\ Aristóteles
}

O presente estudo propõe-se a investigar a origem do ministério episcopal, na medida em que é observável nos escritos do Novo Testamento ${ }^{1}$.

Depois de uma breve introdução metodológica, recolhem-se sinteticamente as principais informações do Novo Testamento sobre os ministérios eclesiais, em sua totalidade, diversidade e unidade.

O passo seguinte consistirá na tentativa de esboçar, em seus traços essenciais, o quadro cronológico dos principais ministérios, situandoos em seu contexto eclesial e histórico.

${ }^{1}$ Cf. E. CATTANEO, I ministeri nella Chiesa antica. Testi patristici dei primi tre secoli, Milano, 1997, pp. 93-109. 
Este procedimento - articulado com outras considerações - deverá tornar possível compreender a razão histórica da emergência dos "presbíteros-epíscopos" na Igreja do Novo Testamento.

Em seguida, perguntar-nos-emos pela razão formal, que, estreitamente ligada à razão histórica, nos forneça a chave hermenêutica do sentido do ministério presbiteral-episcopal na Igreja ${ }^{2}$.

Finalmente, apontaremos as forças e as fraquezas da configuração concreta que este ministério assumiu particularmente nas Cartas Pastorais.

\section{Introdução metodológica}

Em todo este empreendimento, procurar-se-á respeitar a natureza própria dos textos do Novo Testamento com suas múltiplas implicações.

Antes de tudo, procurar-se-á respeitar os textos neotestamentários em sua dimensão literária e em seu alcance histórico, destacando a originalidade própria de cada livro do Novo Testamento, para não nivelar, com fáceis generalizações, informações muito complexas.

Tomar-se-á também o cuidado de não confundir "estrutura", "organização" e "figuras" ministeriais. A estrutura será entendida como uma totalidade orgânica de elementos de tal forma inter-relacionados que a mudança de lugar ou a modificação de um acarreta a mudança de lugar ou a mudança correlativa dos demais. Uma estrutura é móvel e, portanto, aberta a variações de grande amplitude, porém dentro de certos limites, além dos quais perde sua identidade. A estrutura não se confunde com as formas concretas de organização que pode revestir e as diversas figuras que pode adotar. Nos textos do Novo Testamento, dever-se-á discernir o que pertence ao domínio da estrutura e o que pertence ao nível da organização, perguntandose se a diversidade das organizações conduz ou não à unidade de uma estrutura ${ }^{3}$.

${ }^{2}$ Cf. S. DIANICH, Teologia del ministero ordinato. Una interpretazione ecclesiologica, Roma, 1984, pp. 111-129.152-202.

${ }^{3}$ Embora usando outra terminologia, vários autores trabalham com essa distinção: "estrutura" e "estruturas" (Y. CONGAR, Ministères et communion ecclésiale, Paris, 1971, pp. 46-49), "estrutura teológica" e "sociologia desta estrutura" (J. J. von ALLMEN, L'Esprit Saint et l'Église, Neuchâtel-Paris, 1969, p. 73); B. SESBOÜE, "Ministerios y estructura de la Iglesia", in J. DELORME (org.), El ministerio y los ministerios según el Nuevo Testamento, Madrid, 1975, pp. 322-325. 
Na reflexão sobre o Novo Testamento, supõem-se a mútua implicação entre Novo Testamento e Igreja, por um lado, e a necessária referência à unidade do Novo Testamento, por outro.

Particularmente numa reflexão sobre ministérios, é obrigatório trazer à consciência o fato de que o processo de formação do Novo Testamento - que, na verdade, é um complexo processo de tradição da fé - constitui um ato ministerial fundamental, que é inerente ao ser da Igreja: não só o primeiro de uma série, mas o primordial e constitutivo e, por isso, normativo.

Da mesma forma, o Novo Testamento não poderá ser autenticamente interpretado fora ou contra o pressuposto de sua unidade, pelo fato de que, a despeito das peculiaridades, das divergências e até mesmo de contradições entre livros e/ou textos, a Igreja antiga, ao acolhê-los e inscrevê-los no cânon, os considerou todos como expressão coerente da mensagem cristã ${ }^{4}$. A difícil tensão dialética entre unidade $e$ diversidade deve ser cuidadosamente mantida, evitando seja uma leitura uniformizadora seja uma leitura dissociadora do Novo Testamento.

Na verdade, a unidade do Novo Testamento - expressa também na unidade do cânon - indica, antes de mais nada, a unidade da Igreja, pois as comunidades cristãs onde se formaram os diversos documentos que compõem o Novo Testamento consideram-se reciprocamente como a expressão da mesma Igreja de Jesus Cristo. Esta unidade pressupõe, por sua vez, a consciência da unidade da mensagem cristológica e do mistério cristão: "Há um só corpo e um só Espírito... uma só esperança, um só Senhor, uma só fé, um só batismo, um só Deus e Pai de todos" (Ef 4,4-5).

Igualmente, a atenção à diacronia e à sincronia proporciona alguns princípios importantes para se resgatar, indissoluvelmente, a diversidade e a unidade da mensagem do Novo Testamento.

Em primeiro lugar, não se pode transcurar a questão da gênese do Novo Testamento, que se estendeu por, no mínimo, três quartos de século, sendo, portanto, absolutamente normal um desenvolvimento como resultado da evolução das situações eclesiais e da reflexão sobre questões novas a partir da experiência acumulada.

Duas tentações deverão ser evitadas: dar mais valor ao mais primitivo e ao mais próximo do acontecimento fundante (tendência mais

${ }^{4}$ Cf. H. SCHLIER, Essais sur le Nouveau Testament, Paris, 1968, p. 15 e 24-25; W.
KASPER, Il dogma sotto la parola di Dio, Brescia, 1968, p. 112; B. PASCAL, Pensées, n. ${ }^{\circ} 257$. 
própria dos protestantes) ou, no outro extremo, dar mais valor ao mais desenvolvido, estabelecendo a norma da vida eclesial a partir dos últimos documentos do Novo Testamento (tendência mais congenial aos católicos).

Por outro lado, impõe-se situar o resultado da gênese dentro da sincronia, procurando resgatar a unidade teológica imanente desta totalidade plural.

É importante ainda advertir que o testemunho do Novo Testamento sobre os ministérios diz respeito a realidades que se inscrevem na vida concreta e se expressa através de uma rede de relações institucionais vigentes nas e entre as comunidades, que só ocasionalmente são objeto de um discurso explícito, mas, mesmo assim, quase sempre episódico e fragmentário. "A Igreja fala de Cristo e não antes de tudo de si mesma; apresenta-se ao falar de Cristo e anunciar Sua palavra. Decorre daí que o valor estrutural dos ministérios não costuma encontrar-se diretamente, mas está implicado na relação do autor com os destinatários" ${ }^{\prime \prime}$.

Por isso, é necessário tomar algumas precauções. "Não é verdade a priori, por exemplo, que a reflexão própria de cada livro do Novo Testamento carregue uma intenção eclesiológica suficiente para que os elementos fundamentais da estrutura da Igreja se manifestem nela e se tenha que tirar conclusões válidas... a estrutura real da Igreja não está necessariamente refletida na estrutura do discurso... O argumento $a$ silentio poderia provar qualquer coisa"6.

É também importante respeitar a articulação entre o dado histórico c o alcance teológico: "É claro - por exemplo - que a 1Cor no que se refere aos ministérios é um documento muito mais antigo e, sem dúvida, mais fiel do ponto de vista histórico que os Atos dos Apóstolos, que são uma releitura dos primeiros tempos redigida com algumas intenções teológicas bem determinadas. Porém não se deve generalizar isso, e a crítica recente tem descoberto indicações históricas de grande valor em certos documentos que antes eram suspeitos sob este ponto de vista. Por outro lado, não é justo suspeitar a priori das intenções teológicas. Os documentos mais antigos também as possuem - na 1Cor temos um claro exemplo disso - ainda que sejam mais espontâneas e menos formais"

\footnotetext{
${ }^{5}$ B. SESBOÜÉ, Op. cit., p. 336.

' Idem, p. 336

7 Idem, p. 337; cf. R. PENNA, "Lineamenti di storia della Chiesa primitiva", in: $R$. FABRIS (org.), Introduzione generale alla Bibbia, Torino, 1994, p. 127; G. SCHNEIDER, Gli Atti degli Apostoli, I, Brescia, 1985; M. HENGEL, La storiografia protocristiana, Brescia, 1985; R. PENNA, L'ambiente socio-culturale delle origini cristiane. Una documentazione ragionata, Bologna, 1991 ( $3^{\mathrm{a}}$ ed.).
} 
Por último, convém ter em conta que cada livro do Novo Testamento é, a seu modo, como foi dito acima, um ato ministerial. O missionário fundador de uma Igreja (ou alguém ligado diretamente ao grupo apostólico) e responsável por essa Igreja exerce seu ministério escrevendo-lhe ${ }^{8}$. Os Evangelhos - cuja composição final é atribuída a um apóstolo ou companheiro dos apóstolos - consignam por escrito as tradições da pregação oral a respeito do Evangelho. $\mathrm{O}$ ato eclesial de fixar o cânon é também um ato ministerial de anúncio da palavra dita uma vez por todas a todo cristão. Este conjunto de atos ministeriais de caráter fundante é uma referência normativa para os ministérios "fundados", chamados a perpetuar-se na Igreja.

\section{Panorama ministerial do Novo Testamento ${ }^{9}$}

\subsection{As Cartas Paulinas}

\subsubsection{Ministros das Igrejas locais}

Antes de tudo, Paulo faz uma referência a pessoas que desempenham uma atividade não muito bem precisada nas comunidades locais. Escrevendo aos Tessalonicenses, ele pede que estes tenham consideração por "aqueles que labutam (kopiôntas) entre vós, que vos presidem (proistaménous) no Senhor e vos repreendem (nouthetoûntas). Tratai-os com muito respeito e caridade, por causa do seu trabalho (érgon)" (1Ts 5,12-13). Quase nos mesmos termos, ele recomenda aos Coríntios: "Sabeis que Estéfanas e sua família são as primícias (aparché) da Acaia; eles se dedicaram ao serviço (diakonían) dos santos. Tende, pois, deferência com pessoas de tal valor e para com todos os que colaboram (synergoûnti) e se afadigam (kopiônti) com eles" (1Cor 16,1516). Nos dois casos, Paulo pede explicitamente que a comunidade reconheça e aceite o ministério de alguns de seus membros.

$\mathrm{Na}$ organização da coleta em favor da Igreja de Jerusalém, Tito é o delegado do Apóstolo (cf. 2Cor 8,6-23; 12,17-18), e a Igreja de Corinto deve escolher os seus delegados (cf. 1Cor 16,3), bem como acolher os delegados das demais Igrejas (cf. 2Cor 8,22-23).

\footnotetext{
${ }^{8}$ Paulo, por exemplo, nos cabeçalhos de suas cartas, apresenta-se como "apóstolo" (Gl 1,1) ou "apóstolo de Jesus Cristo" (cf. 1Cor 1,1; 2Cor 1,1; Rm 1,1), etc.

${ }^{9}$ Em função do espaço não nos detivemos nas informações que os Evangelhos contêm sobre ministérios (por exemplo, cf. J. DELORME, "El Evangelio según San Marcos", in J. DELORME (org.), El ministerio ..., Op. cit., pp. 148-171; S. LÉGASSE, "El Evangelio según San Mateo", in Idem, pp. 172-194; A. GEORGE, "Los ministerios según el Evangelio de Lucas", in Idem, pp. 217-224).
} 
Escrevendo aos Romanos, Paulo apresenta oficialmente e recomenda Febe, 'nossa irmã', 'ministro (diákonos)' da Igreja em Cencréia (cf. Rm 16,1-2).

A presença de ministros na comunidade de Filipos é claramente atestada. Não se pode silenciar o fato de que, numa de suas primeiras Cartas, a Carta aos Filipenses, Paulo se dirija "a todos os santos em Jesus Cristo que estão em Filipos, com os seus episkopos $e$ diákonos (syn epískopois kai diakónois)" (FI 1,1 ${ }^{10}$.

Por sua vez, o texto de Gl 6,6 - "Aquele que é instruído na doutrina, partilhe aquilo que possui com quem o instrui" - alude muito provavelmente a um ministério encarregado do ensinamento ou da catequese naquela(s) comunidade(s).

\subsubsection{Listas de carismas, serviços e ministérios}

Além dessas referências não muito bem precisadas, em algumas passagens de suas Cartas, Paulo cataloga os dons, as atividades, as diversas funções existentes na Igreja: 1Cor 12,4-11; 12,28-31; 14,6; Rm 12,6-8; (Ef 4,11-12).

Nestas listas, Paulo não coloca tudo no mesmo nivel: em alguns casos, enumera os dons seguindo uma certa ordem (cf. 1Cor 12,28) e insiste em que se aspire aos dons melhores (cf. 1Cor 12,31; 14,1).

Se para os Coríntios se trata de manifestações "pneumáticas" (cf. 1Cor 12,1) e mais ou menos extáticas (cf. 1Cor 12,1-3), para Paulo se trata de "dons" do Espírito (charísmata), "ministérios" do Senhor (diakoniai) e "operações" do Pai ${ }^{11}$ (energhémata) (cf. 1Cor 12,4-6) dados por Deus para a edificação e o crescimento da Igreja ${ }^{12}$. Nesta linha, é significativo que Paulo relegue para o último plano o "dom das línguas" tão apreciado pelos Coríntios (cf. 1Cor 12,10.30).

\footnotetext{
${ }^{10}$ As palavras episkopos e diákonos provavelmente não têm aqui ainda a acepção técrica de "bispo" e "diácono" nem, muito menos, a configuração própria das Pastorais, mas seu uso numa Igreja paulina antiga merece atenção; neste contexto, os epískopoi kai diákonoi designariam "globalmente os ministros das comunidades novas que surgiram da missão junto aos gentios" (A. LEMAIRE, "Las epistolas de Pablo: la diversidad de los ministerios", in J. Delorme (org.), El ministerio ..., Op. cit., p. 69).

"Cf. K. RAHNER, "Theós", in G. KITTEL / G. FRIEDRICH (org.), Theologisches Wörterbuch zum Neuen Testament, t. III, Stuttgart, 1933-1979, p. 105, em que Rahner conclui assim sua pesquisa: "Esse conjunto de constatações permite afirmar que quando se trata de ho Theós no Novo Testamento, fora as seis passagens acima citadas, é o Pai como a primeira pessoa da Trindade que é designado"; cf. Th. De RÉGNON, Études sur la sainte Trinité, t. I, Paris, 1982, pp. 439-451.

${ }^{12}$ Cf. E. KÄSEMANN, "Amt und Gemeinde im Neuen Testament" (1949), in Exegetische Versuche und Besinnungen I, Göttingen, 1964, pp. 109-134; M. A. CHEVALLIER, Esprit de Dieu et paroles d'hommes, le rôle de l'Esprit dans les ministères de la parole selon l'apôtre Paul, Neuchâtel, 1966, pp. 139-171.
} 
Dentre os dons Paulo destaca três grupos de pessoas que realizam funções distintas: "Os que Deus dispôs na Igreja são, primeiro apóstolos, segundo profetas, terceiro doutores" (1Cor 12,28; cf. v. 29 partim). Chama a atenção o fato de que os membros dessa tríade sejam evocados por "títulos" precisos, enquanto os demais dons não recebem um nome especial: "depois vem o dom dos milagres, depois o da cura, o da assistência, o da direção, e o dom de falar em línguas" (1Cor 12,28).

Os apóstolos ${ }^{13}$ - distintos do grupo dos Doze $e^{14}$ - são missionários enviados oficialmente por uma comunidade cristã para anunciar o Evangelho onde este é ainda desconhecido. Geralmente vão de dois em dois (cf. At 13,2; 15,27...) munidos de cartas de recomendação. A partir do momento em que, numa cidade, a comunidade cristã está fundada e suficientemente sólida, o apóstolo parte para outros lugares. Terminada sua missão, volta à comunidade que o enviou, para prestar contas do resultado de seu trabalho (cf. At 14,27; 18,22). Pelo "acordo de Jerusalém" (cf. Gl 2,9), alguns apóstolos se encarregam da pregação entre os judeus (da Diáspora) e outros, dos pagãos (cf. Rm 11,13; $1 \mathrm{Pd} 1,1 ; \mathrm{Gl} 2,11$; At 28,30, 1Cor 1,12). A prioridade dada aos

\footnotetext{
${ }^{13}$ O termo "apóstolo" no Novo Testamento cobre, pelo menos, quatro significados: a) os Doze discípulos históricos de Jesus; b) as "testemunhas da Ressurreição"; c) as testemunhas tanto da Ressurreição quanto da vida terrena de Jesus; d) os missionários enviados por uma comunidade, tendo como protótipo os antioquenos (cf. J. ROLOFF, Hechos de los Apóstoles, Madrid, 1984, pp. 62ss.).

14 Paulo emprega o apelativo "apóstolos" a um círculo mais amplo e distinto dos "Doze" (cf. 1Cor 4,9; 9,2.5; 12,28.29; 15,7.9; Gl 1,17.19); Mateus aplica uma única vez o título de "apóstolos" aos Doze (cf. Mt 10,2), no contexto do envio em missão; Marcos talvez duas vezes (Cf. Mc 3,14; 6,30); Lucas, seis vezes; só duas vezes ele atribui o título de "apóstolos" aos missionários Paulo e Barnabé (cf. At 14,4.14); nos demais casos (Atos), ele é reservado ao grupo dos Doze: cf. J. DUPONT, "Le nom d'apôtres a-t-il été donné aux Douze par Jésus?", L'Orient Syrien 1 (1956) 425ss.; A. GEORGE, "Des Douze apôtres à leurs successeurs", in Le ministère sacerdotal, Lyon, 1970, pp. 25.53.208ss.; A. DESCAMPS, "Aux origines du ministère: la pensée de Jésus", Revue Théologique de Louvain, $2 / \mathrm{n}^{\circ} 1$ (1971) 3-45; A. LEMAIRE, "Dos serviços aos ministérios. Os serviços eclesiásticos nos dois primeiros séculos", Concilitum $80 / \mathrm{n}^{\circ} 10$ (1972) 1265-1277; R. FABRIS, Jesus de Nazaré - História e interpretação, São Paulo, 1988, pp. 135ss. Os principais estudos sobre os Doze e os Apóstolos são basicamente concordes nos seguintes pontos: a instituição dos Doze remonta ao ministério de Jesus; os Doze foram testemunhas privilegiadas do Ressuscitado; o apostolado é uma instituição essencialmente missionária; o título "apóstolo" provavelmente originou-se na Igreja de Antioquia; primitivamente, o apóstolo é o "missionário" enviado por sua Igreja a anunciar o Evangelho; quando da polêmica contra os apóstolos judaizantes vindos da Palestina, Paulo insiste na visão do Cristo Ressuscitado como fundamento do seu apostolado; esta noção de apostolado foi aceita pouco a pouco; a partir daí, us apóstolos tinham a mesma função dos Doze, i.é, testemunhar o Ressuscitado; esta evolução chega, em Lucas, à identificação total dos dois grupos (apóstolos e Doze) (Cf. A LEMAIRE, "Les ministères dans la recherche néo-testamentaire. État de la question", La Maison-Dieu, 115 (1973) 37-41).
} 
apóstolos nesta tríade ministerial revela a orientação missionária da Igreja, especialmente da comunidade de Antioquia ${ }^{15}$.

Os profetas falam "em Espírito" (cf. 1Cor 14) e desempenham papel importante sobretudo nas assembléias litúrgicas (cf. 1Cor 14,3.4.22), nas quais, além da pregação, realizam a ação de graças ou a "prece eucarística" (cf. 1Cor 14,15-17) ${ }^{16}$. Algumas mulheres também são profetas (cf. 1Cor 11,2-16; At 21,9). De acordo com At 4,36; 13,1; 15,32, os profetas são líderes de importantes comunidades locais (Antioquia, Jerusalém) e de seu meio eram escolhidos os apóstolos-missionários. Paulo reconhece-lhes uma grande importância (cf. 1Ts 5,20; 1Cor 14,1; Rm 12,6).

Os doutores aparecem geralmente associados aos profetas (cf. At 13,1; Didaqué 15,1: "profetas e doutores"). São responsáveis pela "didaskalía": um ensino mais metódico e sistemático, baseado nas Sagradas Escrituras, conforme faziam os rabinos judeus; aliás, muitos doutores cristãos eram certamente rabinos convertidos, como, por exemplo, Paulo (cf. At 22,3) e Apolo (cf. At 18,24).

A inserção desta tríade ministerial numa lista de dons evidencia a relação existente entre dom (chárisma) e ministério (diakonía). Apóstolos, profetas e doutores são ministros (diákonoi). Paulo também se apresenta como ministro (diákonos) (cf. 1Cor 3,5; 2Cor 3,6; 6,4; cf. Ef 3,$7 ; \mathrm{Cl} 1,23.25$ ) e reconhece seus rivais (super-apóstolos ou falsos profetas) também como ministros (diákonoi) (cf. 2Cor 11,5-22). Apóstolos, profetas e doutores são, ao mesmo tempo, "carismáticos". Ao colocar esta tríade ministerial encabeçando uma lista de dons, Paulo está afirmando que os ministérios (diakoniai) são dons (charismata). Para Paulo não faz sentido opor "carisma" e "ministério" estabelecido (cf. 1Cor 12,28: étheto! $)^{17}$.

Se compararmos a nomenclatura 'precisa' usada para designar esta tríade ministerial com a terminologia 'imprecisa' usada para os demais dons (e serviços), "parece que nesta época os apóstolos, profetas

\footnotetext{
${ }^{15}$ J. GNILKA, "Geistliches Amt und Gemeinde nach Paulus", Kairós 11 (1969) 95.97.104; R. SCHNACKENBURG, "Apostles before and during Paul's time", in Apostolic History and the Gospel, Grand Rapids, 1970, pp. 298, 301; A. LEMAIRE, "Dos serviços aos ministérios. Os serviços eclesiásticos nos dois primeiros séculos", Concilium $80 / \mathrm{n}^{\circ} 10$ (1972) 1265-1277.

${ }^{16}$ Os irmãos devem "deixá-los dar graças (eucharistein) todo o tempo que queiram" (Didaqué 10,7; cf. 1Cor 14,15-17).

i7 "Foi ele que estabeleceu alguns como apóstolos, outros como profetas..." (Ef 4,11); cf. críticas à oposição pretendida por Harnack entre ministérios "carismáticos" e "institucionais": A. LEMAIRE, Les ministères aux origines de l'Église, Paris, 1971, pp. 101ss.; artigos de R. PESCH, P. GRELOT e J. BUDILLON, Istina 16 (1971), pp. 437-488.
} 
e doutores são os únicos ministros para os quais o vocabulário está relativamente estabelecido" ${ }^{\prime 18}$.

A lista de Rm 12,6-8, por sua vez, distingue, de um lado, funções (cf. vv. 6-8a), e, de outro, atitudes pessoais que devem acompanhar seu exercício (cf. restante do v. 8). Assim, "a profecia (profeteía), o ministério (diakonía), o ensino (didaskalía), precedidos todos pela palavra "depois" (eite), formam, portanto, um grupo à parte que devemos relacionar com a tríade "apóstolos, profetas, doutores". Em Rm 12 , Paulo pensa numa comunidade local: compreende-se com facilidade que não tenha mencionado o apostolado, enquanto que a atividade dos profetas e doutores está claramente expressa pela profecia, pelo ensino e pela exortação $(R m 12,7)$, estando esta última diretamente ligada à atividade dos profetas, segundo 1 Cor 14,3"19.

Para Paulo, portanto, "os ministérios são carismas, dons de Deus para o bem de todos; os ministérios dos apóstolos, profetas e doutores encabeçam os carismas dados à Igreja; os nomes dos ministros oficiais, nesta época e pelo menos nas Igrejas relacionadas com o centro missionário de Antioquia, são "apóstolos", "profetas" e "doutores", o que significa que estes ministros são essencialmente ministros da palavra; esses ministérios, porém, não constituem todos os dons feitos por Deus à Igreja: existe, além deles, uma grande variedade de dons e funções que são designados com um vocabulário muito variável"20.

\subsubsection{Colaboradores de Paulo}

Lugar importante enfim ocupam os colaboradores de Paulo, especialmente Barnabé, Silas e Apolo, que trabalham em pé de igualdade com ele (cf. 1Cor 3,5), não dependem de sua autoridade e são, explícita ou implicitamente, chamados de apóstoloi (cf. 1Cor 4,9 - Apolo; 1Cor 9,5s e At 14,4.14 - Barnabé; 1Ts 2,7 - Silas).

Os demais colaboradores do Apóstolo dependem mais de sua autoridade. Nesta condição estão Timóteo, Tito, Epafras, Epafrodito e Tíquico: são auxiliares valiosos de Paulo, participam no ministério apostólico de Paulo subordinados a ele e são chamados de 'diákonoi' (cf. 1Ts 3,2; 2Cor 3,6; 6,4 - Timóteo; Cl 1,7 - Epafras; Ef 6,21; Cl 4,7 Tíquico). Onésimo está associado a Tíquico na missão em Colossos que Paulo lhes confia (cf. $\mathrm{Cl} 4,7.9$ ), mas parece que está começando a ajudar o Apóstolo, que o queria como auxiliar (cf. Fm 13). Na verdade, Paulo sente a necessidade de novos auxiliares: embora ainda estejam com ele um tal Jesus, chamado Justo, Marcos, Aristarco, Demas e Lucas

${ }^{18}$ A. LEMAIRE, "Las epistolas de Pablo: la diversidad de los ministerios", Op. cit, p. 65

${ }^{19}$ Idem, p. 65.

${ }^{20}$ Idem, p. 65. 
(cf. Fm 24), ele constata que Aristarco, Marcos e Jesus são os únicos colaboradores judeus que lhe restam ( $\mathrm{cf} . \mathrm{Cl} 4,11)$ e procura completar sua equipe missionária com cristãos vindos do paganismo. Este grupo tão heterogêneo de "irmãos" forma, porém, uma verdadeira equipe missionária animada por Paulo.

Em resumo, as Cartas Paulinas atestam, portanto, a existência de servidores da comunidade, ministros numerosos e diversos, às vezes missionários, às vezes a serviço de uma Igreja local. Com exceção da tríade ministerial procedente da tradição, Paulo parece dar mais importância às funções que aos títulos: o importante é que sejam servidores fiéis (cf. 1Cor 3,$6 ; 4,2$ ) que comprovem com sua atividade a graça de que são portadores.

A diversidade carismático-ministerial é querida por Deus, é obra do Espírito (cf. 1Cor 12,4-11; 12,28; Rm 12,6). Todo ministério é dom (chárisma) de Deus: Deus é quem os "estabelece" na Igreja (cf. 1Cor $12,28)$; é Cristo que "outorga" a cada um uma função diferente (cf. Ef 4,11). Esta diversidade se dá no interior da Igreja (1Cor 12,28: en té ekklesía) e visa à edificação (oikodomé) do corpo de Cristo (Ef 4,12; cf. 1 Cor 14,3.4.;14,12; 2Cor 12,19).

\subsection{A Carta aos Colossenses, o bilhete a Filemon e a Carta aos Efésios}

Na Carta aos Colossenses, Paulo, "apóstolo de Jesus Cristo pela vontade de Deus" $(\mathrm{Cl} 1,1)$, se apresenta como diákonos do Evangelho e da Igreja (cf. $\mathrm{Cl} \mathrm{1,23.25),} \mathrm{pelo} \mathrm{que} \mathrm{ele} \mathrm{se} \mathrm{afadiga} \mathrm{(kopiô)} \mathrm{e} \mathrm{luta}$ (agonizómenos) (cf. $\mathrm{Cl} \mathrm{1,29),} \mathrm{anunciando} \mathrm{Cristo,} \mathrm{advertindo}$ (nouthétoûntes) e instruindo (didáskontes) (cf. $\mathrm{Cl} \mathrm{1,28).} \mathrm{A} \mathrm{Igreja} \mathrm{de}$ Colossos deve ter sido dotada dos ministérios necessários, pois Epafras, "amigo e companheiro de serviço" de Paulo e "fiel ministro do Cristo" (cf. Cl 1,7-8; 4,12-13), pode deixar esta comunidade para encontrar-se com Paulo. Epafras, na verdade, parece desempenhar seu ministério numa área que vai além da cidade de Colossos (cf. $\mathrm{Cl} 4,13$ ). Entre os ministros da Igreja de Colossos, Paulo menciona explicitamente Arquipo: "Dizei a Arquipo: "Considera o ministério (diakonían) que recebeste (parélabes) no Senhor e procura cumpri-lo bem" $(\mathrm{Cl} 4,17)$. De acordo com o bilhete a Filemon, Arquipo faz parte de sua casa. Esta casa era o lupar de reunião da comunidade cristã (cf. Fm 2). Parece que aquele, ue recebe a comunidade em sua casa desempenha um papel importante nessa comunidade ${ }^{21}$. Deve ser também o caso de

${ }^{21}$ Cf. A. JAUBERT, "Las epistolas de Pablo: el hecho comunitario", in J. DELORME (org.), El ministerio ..., Op. cit., p. 27. 
Ninfas (provavelmente uma mulher) em Laodicéia, onde a assembléia se reúne em sua casa (cf. $\mathrm{Cl} 4,15$ ). Nas saudações finais, Paulo apresenta alguns de seus colaboradores mais diretos: Tíquico, "ministro

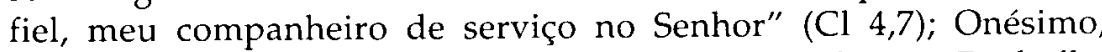
Aristarco, Jesus, etc. (cf. Cl 4,9-14). Escrevendo a Filemon, Paulo the solicita a libertação de Onésimo, de modo que este possa "servir" (diakoné) ao Apóstolo "nas cadeias do Evangelho" (Fm 13).

A Carta aos Efésios não tem como horizonte de referência a vida concreta de uma Igreja local ${ }^{22}$, mas se interessa pelo conjunto da Igreja, como manifestação do mistério escondido em Deus desde a criação do mundo, como Igreja aberta a todos os povos, como lugar de comunhão de judeus e gentios e, por isso, como promessa da reconciliação universal em Cristo (cf. Ef 1,10; 2,11-17). Os "apóstolos e profetas" entram na própria definição da Igreja, uma vez que esta é a construção/casa onde os pagãos não são mais "estrangeiros nem hóspedes, mas concidadãos dos santos e familiares de Deus, edificados sobre o fundamento dos apóstolos e profetas, e tendo como pedra angular o próprio Cristo Jesus" (Ef 2,19-20). Aqui, como nas Cartas de Paulo, o termo "apóstolos" designa um grupo bastante amplo de testemunhas do Ressuscitado, enviados a evangelizar e a fundar Igrejas; os "profetas", por sua vez, juntamente com os apóstolos, são os instrumentos da revelação do mistério "que não foi manifestado aos homens das precedentes gerações como agora foi revelado aos seus santos apóstolos e profetas por meio do Espírito" (Ef 3,5). Os profetas cristãos eram os líderes das primeiras comunidades (cf. At 13,1) e, de acordo com 1 Cor 12,28, ocupam o segundo lugar entre os ministros que Deus estabeleceu na Igreja, logo depois dos apóstolos.

Por isso, a Carta aos Efésios reserva uma parte importante para o ministério de Paulo (cf. Ef 3,1-13), que foi justamente o campeão da abertura aos pagãos, e seu ministério é o espelho mais claro de que a Igreja dispõe para compreender-se e identificar-se como a realização do mistério. O ministério dos "apóstolos e profetas" - realizado de forma insuperável em Paulo - enquanto momento decisivo do desvelamento do mistério, não pode ter sucessores neste aspecto; "apóstolos e profetas" são uma grandeza única, que pertence ao ephapax (uma vez por todas) do evento da salvação.

A revelação do mistério é, portanto, uma graça dada uma vez por todas no ministério dos "apóstolos e profetas", mas é também uma responsabilidade e uma tarefa eclesiais. O hoje da revelação é um hoje

${ }^{22}$ Cf. P. BONY, "La epistola a los Efesios", in J. DELORME (org.), El ministerio ..., Op. cit,, p. 76; cf., pelo contrário, $\mathrm{Cl} 4,15-17$ 
eclesiológico ${ }^{23}$. Daí porque o apelo à unidade (cf. Ef 4,4-6) é uma exigência primordial inscrita no próprio ser, vocação e missão da Igreja. A unidade é a meta do crescimento de todo o corpo (cf. Ef 4,7-16) e todos são responsáveis por ela. Na edificação deste corpo, porém, "cada um de nós" (cf. Ef 4,7), "cada membro" (cf. Ef 4,16) tem uma função própria, proveniente da mesma graça fundamental de Cristo: "A cada um de nós, todavia, foi dada a graça segundo a medida do dom de Cristo" (Ef 4,7).

Os ministérios são, pois, dons de Cristo a seu corpo para o crescimento do corpo, de que Cristo é a cabeça: "Foi Ele que estabeleceu alguns como apóstolos, outros como profetas, outros como evangelistas, outros como pastores e mestres, para tornar os irmãos idôneos a realizar o ministério, a fim de edificar o corpo de Cristo, até que cheguemos todos à unidade da fé e do conhecimento do Filho de Deus, ao estado do homem perfeito, na medida que convém à plena maturidade de Cristo" (Ef 4, 11-13). À tríade tradicional de ministros da palavra de 1 Cor 12,28, a lista de Ef 4,11 acrescenta "evangelistas" e "pastores", intercalando-os entre o segundo e o terceiro membro da tríade. O Novo Testamento, na verdade, conhece dois "evangelistas": Felipe (At 21,8; cf. At 8,5.40) e Timóteo (cf. 2Tm 4,5). O fato de, na lista de Ef 4,11, os "evangelistas" aparecerem depois dos apóstolos e profetas talvez indique que seu ministério era considerado afim ao dos fundadores das Igrejas e continuador do trabalho apostólico. É provável que fossem ministros responsáveis de grandes centros, que evangelizavam toda a região circunstante ${ }^{24}$. Talvez os "pastores" de Ef 4,11 fossem os responsáveis locais das comunidades locais, juntamente com os doutores (At 20,28-31; cf. 1 Pd 5,2).

\subsection{As Epístolas Pastorais}

Escritas por um discípulo de Paulo na última quarta parte do século I, as Epístolas Pastorais refletem as preocupações das comunidades cristãs, que, à luz dos ensinamentos e dos exemplos do Apóstolo, procuram viver as exigências do Evangelho na situação criada pelo desaparecimento do seu fundador. Seu autor, apoiando-se na tradição litúrgica e disciplinar de sua comunidade, propõe-se a defender a mensagem do Apóstolo diante das interpretações gnósticas que se lhe faziam. Ele quer mostrar como os ministros devem "cuidar da casa de Deus" (1Tm 3,5), romo devem "portar-se na casa de Deus que é a Igreja do Deus vivo" $(1 \mathrm{Tm} 3,15)$, preocupado que está com "a admi-

${ }^{23}$ Cf. P. BONY, "La epistola a los Efesios", in J. DELORME (org.), El ministerio ..., Op. cit., p. 83; cf. J. GNILKA, Der Epheserbrief, Freiburg, 1971.

${ }^{24}$ Cf. A. LEMAIRE, Les ministères aux origines de l'Église, Op. cit, p. 187. 
nistração da casa de Deus na fé" (1Tm 1,4; cf. 1Cor 3,10-15; 2Tm 2,19). Nesta perspectiva, as Cartas Pastorais ocupam-se fundamentalmente de três temas: o apostolado de Paulo, o ministério de alguns de seus discípulos e colaboradores, alguns ministérios da Igreja local.

O apostolado de Paulo é tratado sob três aspectos: a vocação à missão apostólica, o exercício da missão apostólica, a mística do apóstolo.

As Pastorais insistem em que o Apóstolo foi chamado diretamente por Deus (cf. $1 \mathrm{Tm} 1,1 ; 1,12 ; 2 \mathrm{Tm} 1,1.8 ; \mathrm{Tt} 1,3$ ), ressaltando assim que a eleição de Paulo para o apostolado se deve a uma pura graça (cf. $1 \operatorname{Tm} 1,12.13 .14 .16 ; 2 \operatorname{Tm} 1,9 ; 4,17)$, que o "estabeleceu" no ministério (cf. $1 \mathrm{Tm} 1,12 ; 2,7 ; 2 \operatorname{Tm~} 1,11 ; 2 \operatorname{Tm} 4,7 ; \mathrm{Tt} 1,3$ ). A finalidade deste chamado - tanto para Paulo como para os que, a seu tempo, serão chamados à missão apostólica - é antes de tudo o anúncio do Evangelho (cf. 1Tm 2,7; 2Tm 1,1.11; Tt 1,1-2; cf. 1Cor 1,17).

Na ótica das Pastorais, Paulo não está ligado a nenhuma Igreja particular, mas tem a responsabilidade de todas as comunidades que fundou (cf. 1Tm 1,3 - Igreja de Éfeso; Tt 1,5 - Igrejas de Creta), nos mais diversos campos: pregação e ensino; organização institucional; culto e assembléias litúrgicas; conduta dos fiéis na vida. É sabido que as Pastorais, sem prejuízo do anúncio (cf. por exemplo $1 \mathrm{Tm} 2,4$ ), preocupam-se, sobretudo, com a conservação da doutrina em toda a sua pureza. Se, nas grandes epístolas, o acento recai sobre a fides qua, nas Pastorais, enfatiza-se sobretudo a fides quae: a fé é antes de tudo fidelidade a um corpo de doutrina, a um credo oficial, pedra de toque da ortodoxia (cf. por exemplo $1 \mathrm{Tm} 4,1 ; 6,21 ; \mathrm{Tt} 1,4$ ). Neste contexto, compreende-se a insistência do autor na necessidade de lutar contra os falsos doutores, que "se desviam da verdade", que "voltam as costas para a verdade" (cf. 1Tm 1,3-7; 4,1-16; 6,3.5; $2 \mathrm{Tm} 2,14.16 ; 3,1-17$; Tt $1,10-16 ; 3,9-11$ ). (A única vez em que aparece no Novo Testamento a palavra "herege" é em Tt 3,10!) Mas é importante perceber que as Pastorais não estão preocupadas com a ortodoxia a despeito da ortopráxis; estão igualmente preocupadas pelas práticas que a falsa doutrina gera ou justifica (cf. 1Tm 4,25; 6,5; 2 Tm 3,1-9; Tt 1,16; 2,12), pois a finalidade da reta doutrina é "o amor que procede de um coração puro" $(1 \mathrm{Tm} 1,5)^{25}$.

Uma poderosa mística impulsiona e sustenta a missão apostólica, sendo a oração, o combate por Cristo, a esperança nas dificuldades e a oblação da vida aos irmãos seus elementos principais. ${ }^{25}$ Cf. J. I. GONZÁLEZ FAUS, Hombres de la comunidad. Apuntes sobre el ministerio
eclesial, Santander, 1989, pp. 66ss. 
Para dar conta da solicitude por todas as Igrejas, Paulo recorre à ajuda de numerosos colaboradores, que são encarregados com freqüência de alguma missão nas comunidades locais. Estes colaboradores formam uma equipe itinerante disposta a intervir, com a autoridade do Apóstolo, onde seja necessário (Timóteo: cf. 1Tm 1,3 com $2 \mathrm{Tm}$ 4,9.21; Tito: Tt 1,5 com 3,12; Trófimo: 2Tm 4,20; Lucas e Marcos: $2 \mathrm{Tm}$ 4,11). As Pastorais aludem com frequiência à sua entrada em função, precisam sua missão e abordam o problema de sua sucessão.

O autor evoca várias vezes a cerimônia de investidura de Timóteo: "Não descuides o carisma que há em ti, que te foi conferido por uma intervenção profética, acompanhado da imposição das mãos pelo colégio dos presbíteros" $(1 \mathrm{Tm} 4,14)$. "Recordo-te que tens de reavivar o carisma de Deus que está em ti desde que te impus as mãos" (2Tm 1,6; cf. $1 \mathrm{Tm} 1,18 ; 6,12)$.

Esta investidura comporta diversos aspectos: (a) a profecia pronunciada sobre o candidato (cf. $1 \mathrm{Tm} 1,18$ ), que provavelmente era uma oração litúrgica (cf. Lc 1,67; 1Cor 14; Didaqué X,7); (b) a imposição das mãos pelo "colégio dos presbíteros" ou, mais provavelmente, a imposição das mãos para transmitir a dignidade de "ancião", numa muito provável adaptação da "semikhat zeqenim", a investidura rabínica ${ }^{26}$; (c) a profissão de fé perante numerosas testemunhas $(1 \operatorname{Tm} 6,12$; cf. $1 \mathrm{Tm}$ 1,18); (d) a conferição do dom (carisma) ligado expressamente à imposição das mãos, sem nenhuma oposição entre "carisma" do Espírito (cf. 2 Tm 1,6-7) e "ministério", como na investidura prototípica de Josué por Moisés (Dt 34,9; cf. Nm 11,24-30; 27,15-23); trata-se, na verdade, de um "dom de Deus" (2Tm 2,16; cf. também 1Tm 4,14; 2 Tm $1,7)$.

O dom do Espírito Santo (cf. 1 Tm 4,14; 2 Tm 1,7; 2,16) habilita os colaboradores de Paulo para o ministério, que consiste essencialmente no "ensino" (a palavra "didaskalía" aparece pelo menos quinze vezes nas Pastorais), velando especialmente pela fidelidade e solidez da doutrina: "Conserva o bom depósito pelo Espírito Santo que habita em nós" (2Tm 1,14; cf. Jo 14,26). Este ensino comporta o anúncio da palavra a todos (cf. 2Tm 4,2) e se desdobra na "leitura", na "exortação" e no "ensino" sistemático (cf. 1Tm 4,13), sendo a Escritura o principal instrumento do ministério de Timóteo (cf. $2 \mathrm{Tm} 3,16$ ), dandolhe "inteira autoridade" (Tt 2,15; cf. 1Tm 1,3; 4,11; 5,7; 6,13.17). Esta autoridade abarca a organização da oração litúrgica (cf. 1Tm 2,1-15), a organização da ajuda às viúvas (cf. 1Tm 5,3-16); o estabelecimento

${ }^{26}$ Cf. K. HRUBY, "La notion d'ordination dans la tradition juive", La Maison-Dieu 102 (1970) 30-56; E. COTHENET, "Le prophétisme dans le Nouveau Testament", Supplément au Dictionnaire de la Bible 8 (1972) 1314; E. CATTANEO, Op. cit, pp. 118ss. 


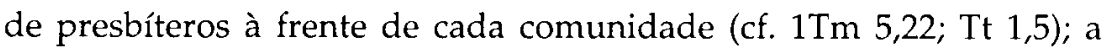
administração da justiça quando um presbítero for acusado (cf. 1Tm 5,19s.); a excomunhão dos recalcitrantes (cf. Tt 3,10).

Além de ministrar o ensino e exercer a autoridade, os colaboradores de Paulo devem também preocupar-se com garantir a transmissão fiel do Evangelho pregado pelo Apóstolo. Esta é, em parte, a função dos presbíteros ordenados por Timóteo (cf. 1Tm 5,22) e por Tito (cf. Tt 1,5): "O que aprendeste de mim na presença de numerosas testemunhas, confia-o a homens fiéis, que, por sua vez, serão capazes de ensinálo a outros mais" $(2 \mathrm{Tm} 2,2)$. O Apóstolo tem certeza de que "a palavra de Deus não está acorrentada" (2Tm 2,9), "pois sei em quem depositei a minha fé e tenho a certeza de que ele tem o poder de guardar o depósito que me é confiado até aquele Dia" $(2 \mathrm{Tm} 1,12)$. Tarefa semelhante deve ter sido realizada por outros colaboradores do Apóstolo em outros lugares: Demas em Tessalônica, Crescente na Galácia, Tito (outra vez) na Dalmácia, Erasto em Corinto, talvez Trófimo em Mileto (cf. 2Tm 4,10s.20; cf. também Tt 3,13 com At 18,24).

Dois grupos de ministros da Igreja local são o foco de atenção das Cartas Pastorais: os "presbíteros-epíscospos" e os "servidoresdiáconos" ${ }^{\prime 27}$.

Os termos presbyteros e epískopos designam funções distintas ou são equivalentes? Sem enveredar pelos detalhes da discussão exegética, algumas coisas podem ser afirmadas com bastante segurança: (a) de um lado, "presbítero" é um título tradicional procedente do judaísmo e eqüivale ao de "ancião", enquanto epískopos designa uma função, a de "vigiar"; (b) de outro lado, ainda que as palavras possam designar as mesmas pessoas (cf. Tt 1,5-7; At 20,17.28; $1 \mathrm{Pd} \mathrm{5,1-2),} \mathrm{nas} \mathrm{Pastorais,}$ o termo epískopos aparece no singular; (c) nas Pastorais, o título presbytero continua sendo tradicional, e o de epískopos vai se impondo para designar o presidente da comunidade ${ }^{28}$.

A configuração do grupo de "presbíteros-epíscopos" é descrita com bastante clareza: (a) são estabelecidos em cada cidade (cf. Tt 1,5) e formam o conselho da comunidade local, conforme o modelo das comunidades judaicas; (b) representam uma autoridade moral na comunidade; por isso, não devem ser recém-convertidos, devem ser "irrepreensíveis" em sua vida pessoal e familiar (Tt 1,6s; 1Tm 3,2) e

\footnotetext{
${ }^{27}$ As Pastorais, além dos "presbiteros-epíscopos" e dos "servidores-diáconos", registram outros termos ministeriais - "apóstolo", "arauto", "doutor", "profeta" (cf. Tt 1,12) - e conhecem outros grupos especiais na comunidade (p. ex., viúvas: cf. 1Tm 5,3-16 jovens: cf. Tt 2,6-8).

${ }^{28}$ Cf. A. LEMAIRE, "Los ministerios en la Iglesia", in J. DELORME (org.), El ministerio .., Op. cit., p. 107.
} 
respeitados pelos de fora (cf. 1Tm 3,7; Rm 12,17; 2Cor 8,21); (c) os "presbíteros-epíscopos" devem velar (episkopêin = vigiar, velar) pelo bom andamento da comunidade, como um bom 'chefe' de familia (cf. $1 \mathrm{Tm}$ 3,4-5); por isso, o epískopos é chamado de "ecônomo de Deus" (Tt 1,7); (d) os "presbíteros-epíscopos" desempenham também o ministério da palavra, particularmente o ensino (cf. 1Tm 3,2; Tt 1,9); (e) são objeto de algumas regras particulares, provavelmente recolhidas da tradição: remuneração (cf. 1Tm 5,17-18), tratamento correto no caso de acusações (cf. 1Tm 5,19-20), prudência na seleção dos candidatos à investidura (cf. $1 \mathrm{Tm} 5,22)^{29}$.

O termo diákonos não tem ainda todas as peculiaridades técnicas do termo "diácono": nas Pastorais, não é referido a Paulo, mas a Timóteo (cf. 1Tm 4,6) e a certos ministros locais (cf. 1Tm 3,8.12); Paulo é chamado de "escravo" (doulos) em Tt 1,1. São mencionados na $1^{\mathrm{a}}$ Carta a Timóteo a respeito da Igreja de Éfeso, e talvez não existissem em todas as Igrejas, mas apenas nos grandes centros ${ }^{30}$. Com os dados presentes nas Pastorais podemos traçar o seguinte retrato desses "servidores-diáconos": (a) devem ter quase as mesmas qualidades exigidas dos "presbíteros-epíscopos" (cf. 1Tm 3,8.9.12); (b) suas funções são extremamente indeterminadas ${ }^{31}$ : parecem uma espécie de 'auxiliares' aos quais se confiavam missões e tarefas diversas de acordo com as necessidades, sobretudo, a comunicação entre as Igrejas (cf. 1Cor 16,3; 2Cor 8,22; Fl 2,19-22) ${ }^{32}$; (c) pouco se sabe sobre sua investidura: "Sejam, também eles, provados primeiro; depois, não havendo neles nada que repreender, exercerão o seu serviço" (1Tm 3,10); (d) nada se fala sobre a sua remuneração (cf. $1 \mathrm{Tm} 3,13$ ); (d) certamente houve "mulheres-diáconos" - "as mulheres igualmente devem ser dignas, não maldizentes, sóbrias, fiéis em tudo" (1Tm 3,11; cf. também Rm 16,1) - o que se conclui seja pelo contexto ministerial de todo o parágrafo seja pelo paralelismo entre os diversos grupos: epískopos (1Tm 3,1-7), "igualmente os diáconos" (1Tm 3,8-10.12-13), "igualmente as mulheres" $(1 \mathrm{Tm} 3,11)$.

\subsection{A Carta aos Hebreus}

A Carta aos Hebreus - um escrito de alta cristologia em chave sacerdotal - contém poucas alusões aos ministérios e sem conexão aparente com o tema sacerdotal.

\footnotetext{
${ }^{29}$ Cf. Idem, p. 109.

${ }^{30}$ Cf. Idem, p. 109.

${ }^{31}$ Cf. E. E. ELLIS, "Paul and his Co-Workers", New Testament Studies 17 (1970-1971) 442

${ }_{32}$ Cf. A. LEMAIRE, Les ministères aux origines de l'Église, Op. cit, pp.135-136.
} 
A comunidade à que se refere a Carta aos Hebreus compreende, por um lado, "guias" ou hegoumenoi e, por outro, os "santos" (nesta ordem): "Saudai a todos os vossos guias e a todos os santos" ( $\mathrm{Hb}$ $13,24)$.

A comunidade é vista como o povo de Deus em marcha para a pátria celeste seguindo a Jesus que guia para a salvação (cf. 2,10). Hebreus tem uma visão fortemente comunitária dos santos, que formam uma comunidade de irmãos (cf. 2,11-12), lugar de encontro dos santos (cf. 3,1; 6,10; 13,24), dos filhos ou discípulos (cf. 2,13), dos amados (cf. 6,9), graças ao Espírito que nela derrama seus dons (cf. 2,4), de modo que os cristãos são partícipes (metochoi) do mesmo chamado de Deus (cf. 3,1; 9,15), partícipes e irmãos de Cristo (cf. 3,14), partícipes do Espírito $(6,4)$.

Apesar de todas as dificuldades da caminhada, a comunidade persiste e assume suas funções: o ofício da palavra (cf. 6,5), o consolo e a exortação mútua (cf. 3,13), o ensino dos mestres (cf. 5,12), a beneficência e a partilha (cf. 13,16), a vigilância (cf. 12,15), a oração (cf. 13,24), a confissão litúrgica da fé (cf. 3,1), a imposição das mãos e a instrução sobre o batismo (cf. 6,2), o culto a Deus (cf. 9,14; 12,28).

Sob o prisma ministerial, três aspectos chamam a atenção neste escrito: a) Hebreus não tem nenhum caráter missionário, e os ministérios missionários parecem inexistentes: mais do que voltar-se para o mundo, a Igreja está voltada para si mesma, tendo na ordem e na santidade seus dois pólos maiores de interesse; b) faltam as expressões técnicas para designar os ministérios, sendo praticamente ausente o vocabulário ministerial (cf. 1,$14 ; 6,10)$; c) somente Cristo exerce o ofício de sumo sacerdote em favor da comunidade, que vive já na esfera do sagrado, não se tematizando a comunidade como povo sacerdotal (cf., pelo contrário, 1Pd 2,5.9; Ap 1,6; 5,10; também Rm 5,2; 6,9-11; 12,1; Ef $2,18)$.

Cristo é o chefe (archegós) sempre presente na vida da comunidade, seu fundador, iniciador do povo de Deus (cf. 2,10), o apóstolo e sumo sacerdote de nossa fé (cf. 3,1), o precursor (pródromos) (cf. 6,20). Mas a comunidade conta também com a presença de vários dirigentes: as primeiras testemunhas (cf. 2,3.4); os guias de outros tempos (cf. 13,7-8); os guias atuais da comunidade (cf. 13,17.24); outros dirigentes além dos "vossos" dirigentes (cf. 13,17.24), entre os quais Timóteo e o autor da epístola (cf. 13,18.22.23).

É importante registrar outras três observações em relação a Hebreus: a) na saudação, os dirigentes aparecem antes dos santos, diferentemente, por exemplo, de Fl 1,1; b) chamando de "guias" tanto os dirigentes passados como os atuais, Hebreus parece enfatizar a perma- 
nência de uma mesma função ministerial ${ }^{33}$; c) apesar da insistência para que "velem" (episkopoúntes) (cf. 12,15), estes guias não são chamados de "epíscopos" nem de "pastores".

Discute-se entre os exegetas se a palavra "guia" (hegoúmenos) seria um nome comum aplicável a ministros concretos como epískopos ou presbyteros ou se seria um título particular usado em algumas comunidades $^{34}$, tendo, mais tarde, sobrevivido - com outra conotação apenas na linguagem monástica .

\subsection{Os Atos dos Apóstolos}

\subsubsection{Igreja de Jerusalém}

\subsubsection{Os apóstolos}

Das 28 vezes em que os apóstolos são nomeados no livro dos Atos, 26 o são na Igreja de Jerusalém. São identificados com os Onze e, depois da eleição de Matias, com os Doze $(1,26 ; 2,14.37 ; 6,2.6)$. Em geral, Lucas não dá este título a Paulo, que o reclama insistentemente (cf. as saudações de $1 \mathrm{Cor}, 2 \mathrm{Cor}, \mathrm{Gl}, \mathrm{Rm}, \mathrm{Cl}$ e Ef, bem como em 1Ts 2,7; 1 Cor 4,$9 ; 9,1.2 ; 15,9 ; 2$ Cor 12,12; Rm 1,5; 11,13), e o dá a vários de seus colaboradores, como se verá mais adiante. Lucas reconhece aos Doze uma missão única: garantir a missão de Jesus. Daí as condições que deve possuir o apóstolo: "Há homens que nos acompanharam durante todo o tempo em que o Senhor Jesus caminhou à nossa frente, a começar pelo batismo de João até o dia em que ele nos foi arrebatado: é preciso pois que um dentre eles se torne conosco testemunha de sua ressurreição" (At 1,21-22) ${ }^{35}$. Os apóstolos receberam seu ofício diretamente de Jesus, que os escolheu (cf. At 1,2 e Lc 6,13), enviou em missão nas aparições (cf. At 1,8 e Lc 24,47-48) e confirmou com o dom do Espírito (At 2,1-47 com At 1,4-5.8 e Lc 24,49).

\footnotetext{
${ }^{33}$ Cf. A. LEMAIRE, Les ministères..., Op. cit, p. 110.

${ }^{34}$ Encontra-se este título em outros textos cristãos (cf. Clemente de Roma, $1 \mathrm{Cl} \mathrm{1,3;1}$ Cl 21,6; no Novo Testamento: At 7,10; 14,12; 15,22; Lc 22,26; Mt 2,6). O Documento de Damasco diz: "(Deus) suscitará para eles um guia justo para conduzi-los pelo caminho de seu coração" $(1,11)$.

${ }^{35}$ As hipóteses explicativas para sua insistência na importância das testemunhas oculares vão desde uma reação defensiva diante da gnose (cf. G. KLEIN, Die Zwölf Apostel. Ursprung und Gehalt einer Idee, Göttingen, 1961, pp. 213-215; C. H. TALBERT, Luke and the Gnostics, Nashville - N. York, 1966), passando por seu objetivo de historiador e historiador sagrado (cf. H. FLENDER, Heil und Geschichte in der Theologie des Lukas, München, 1965, p. 149, nota 10; W.-G. KÜMMEL, "Luc en accusation dans la théologie contemporaine", Ephemerides Theologicae Lovanienses 46 (1970) 277; cf. Lc 1,1-2), até à tese de um "protocatolicismo" lucano (cf. E. KÄSEMANN, "Amt ...", Op. cit, p. 130; "Das Problem des historischen Jesus" Zeitschrift für Katholische Theologie 51 (1954) 125-153), in Versuche I, pp. 198-199.
} 
Segundo Lucas, os apóstolos desempenham as seguintes funções: (a) são testemunhas da ressurreição de Jesus (cf. 1,8; 2,32; 3,15; 5,32; $10,39-42 ; 13,31$; cf. ainda 2,$40 ; 8,25 ; 10,42$ ), sendo a palavra (corroborada por prodígios), juntamente com a oração (cf. $6,2.4)$, seu ministério essencial; (b) têm um papel diretivo muito discreto na Igreja de Jerusalém (cf. 4,35.37; 5,2; 5,1-11; 6,2; 9,26-28) ${ }^{36}$; (c) intervêm também fora de Jerusalém relacionando-se com diversos missionários na qualidade de garantes da unidade (cf. 8,14-17; 11,1-18; 15,12.22-29); (d) seu ministério é exercido colegialmente (cf. 2,14-40; 4,24-30.33; 5,2-3.29-42; $6,2-4 ; 8,14 ; 11,1-2$ ) e em diálogo com a comunidade dos irmãos (cf. $1,15-26 ; 6,2-6 ; 11,1-18)$; (e) por sua própria natureza, sua função específica de testemunhas do Ressuscitado é intransferível: "para Lucas não há uma segunda geração de testemunhas do Ressuscitado, nem por conseguinte de apóstolos, mas a palavra dos Doze aparece para sempre como a palavra de Jesus ${ }^{\prime 37}$.

Lucas mostra particular interesse por Pedro (cf. 2,14.37; 5,3-4.8$9.29 ; 8,14-15 ; 9,32-11,18 ; 11,1-18 ; 12,3-17 ; 15,7-11)$, nomeado 56 vezes nos Atos, que o apresenta como o primeiro dos apóstolos, o homem da palavra e também da missão; freqüentemente, cita-o paralelamente a Paulo, ao qual dedica toda a segunda metade de seu livro. Já Tiago parece representar os judeu-cristãos e ser o responsável pela Igreja local de Jerusalém (cf. 12,17; 21,18).

\subsubsection{Os Sete}

O livro dos Atos é o único a mencionar a instituição (cf. 6,1-6) e a atividade do grupo dos Sete (cf. 6,8-8,2; 8,5-40; 21,8-9). Seus nomes e a área em que exercem sua atividade indicam que pertencem ao judaísmo helenístico. Seu ministério teria sido instituído para enfrentar uma crise surgida entre "helenistas" e "hebreus" na comunidade de Jerusalém. Apesar de o relato da sua instituição apresentá-los como responsáveis pelo "serviço das mesas" (cf. 6,2.4; cf. Lc 10,39-42) - em oposição ao "serviço da palavra", que caracterizaria o ministério dos Doze - nós nunca os encontramos ocupados com o serviço das mesas, mas dedicados à pregação em ambientes helenistas (cf. 6,8-10; 8,26-40) ou samaritanos (cf. 8,4-13), sendo alguns discípulos desses ambientes responsáveis pelo anúncio aos "gregos" em Antioquia (cf. 11,20). Os "Sete" seriam, então, dirigentes do grupo dos discípulos "helenistas" e pioneiros da missão em ambientes da Diáspora. Lucas insiste na subordinação dos "Sete" aos Doze para indicar a unidade do ministé-

${ }^{36}$ Cf. R. SCHNACKENBURG, "Lukas als Zeuge verschiedener Gemeindestrukturen", Bibel und Leben 12 (1971) 233-234.

${ }^{37}$ A. GEORGE, "La obra de Lucas: Hechos y Evangelio", in J. DELORME (org.), El ministerio ..., Op. cit., p. 202. 
rio eclesial dirigido, em última instância, pelos apóstolos ${ }^{38}$. Seja como for, é oportuno lembrar também que nos ambientes judaicos as comunidades locais costumam ser dirigidas por um conselho de sete membros $^{39}$; que Lucas não os chama de diáconos, como, mais tarde, entendeu a tradição, e pensaram alguns comentadores ${ }^{40}$; que os chama simplesmente de "os Sete" e não lhes dá outro título, enquanto aos Doze chama de "apóstolos"; que não lhes apresenta nem sucessores em Jerusalém nem similares em outras comunidades. Parece, portanto, que se trata da organização por uma comunidade local de um ministério particular para uma situação especial ${ }^{41}$, que, com o mudar das circunstâncias, pode ter evoluído.

\subsubsection{Os profetas}

Os Atos referem-se várias vezes aos profetas da Igreja de Jerusalém, mas sempre atuando fora da cidade (cf. 11,27-28; 15,22.27.32; 21,10-11). Nunca menciona sua instituição de acordo com a tradição bíblica, para a qual o profeta é um carismático, suscitado pela intervenção livre do Espírito. Mais do que anunciar o futuro (cf. 11,28; $21,11)$, os profetas exortam os irmãos na assembléia litúrgica $(15,32$; cf. 1Cor 14,1-5.31) e exercem um ministério (missionário?) itinerante ${ }^{42}$.

\subsubsection{Os presbíteros-episcopos}

Os "presbíteros" de Jerusalém são mencionados pelos Atos em três ocasiōes (cf. 11,30; 15,2-16,4; 21,28). Trata-se de uma instituição tradicional no mundo judaico, onde designa o conselho dos responsáveis de uma comunidade ${ }^{43}$. Embora não narre sua criação, o fato de apresentá-los ao lado dos apóstolos e, mais tarde, de Tiago, deixa

\footnotetext{
${ }^{38}$ Além dos comentários de O. BAUERNFEIND, E. HAENCHEN, G. STÄHLIN, M. GOGUEL e E. TROCMÉ, cf. A. LOISY, Le origini del cristianesimo, Milano, 1954; B. REICKE, Glaube und Leben der Urgemeinde, Zürich, 1957, pp. 119-120; H. CONZELMANN, Le origini del cristianesimo. I risultati della critica storica, Torino, 1976; R. SCHNACKENBURG, Op. cit., pp. 236-237.

${ }^{39} \mathrm{Cf}$. H. L. STRACK / P. BILLERBECK, Kommentar zum Neuen Testament aus Midrash und Talmud, II, München, 1924, p. 641; K. H. RENGSTORF, "Epta", Theologisches Wörterbuch zum Neuen Testament, vol. 2, Stuttgart, 1935, p. 630; A. LEMAIRE, Les ministères ..., Op. cit, pp. 51-52; R. SCHNACKENBURG, Op. cit, p. 236.

40 Por outro lado, por exemplo E. SCHWEIZER, La comunità e il suo ordinamento nel Nuovo Testamento, Gribaudi, Torino, 1971, p. 228, nota 682, e J. DUPONT, Il discorso di Mileto (Atti 20,18-36), Roma, 1980, $2^{\text {a }}$ ed., consideram a possibilidade de que, na tradição anterior a Lucas, os Sete tenham sido presbíteros. Cf. também J.-G. PAGÉ, Primavera della Chiesa. Ecclesiologia del Nuovo Testamento, Milano, 1993, p. 113.

${ }^{41}$ Cf. E. SCHWEIZER, Op. cit, p. 59; cf. também At 13,1ss.

${ }^{42}$ Cf. Didaqué (12,1 - 13,1; cf. 11,1-6); A. LEMAIRE, Les ministères ..., Op. cit, pp. 64.70.139-141.

${ }^{43}$ Cf. E. SCHWEIZER, Op. cit, 70ss.; A. LEMAIRE, Les ministères ..., Op. cit, pp. 2127.184 .
} 
supor que surgiram para o serviço da comunidade local para compartilhar e, mais tarde, assumir algumas tarefas do grupo apostólico. Do ponto de vista histórico, porém, as informações de Lucas em At 11,30 e 15,2 não são confirmadas por Paulo (cf. Carta aos Gálatas).

\subsubsection{Comunidades pré-paulinas}

Os Atos dos Apóstolos não fornecem nenhuma informação sobre os ministérios nas comunidades pré-paulinas de Samaria, Damasco, Lida e Jope; em Cesaréia, menciona Felipe como "evangelista" e suas quatro filhas, que profetizam (cf. At 21,8-9).

Lucas, porém, tem muitas informações sobre a Igreja de Antioquia. Como se sabe, foi em Antioquia que teve início a primeira verdadeira e própria evangelização dos pagãos, por obra de alguns dos "helenistas" de Jerusalém dispersados pelo martírio de Estêvão (cf. 11,19-21; cf. 6,18,4); a eles logo se junta Barnabé, enviado por Jerusalém (cf. 11,22-24), o qual vai a Tarso e traz Paulo para Antioquia, onde trabalham juntos por um ano (cf. 11,25-26).

Paulo e Barnabé exercem um ministério de ensinamento (cf. didáxai) em Antioquia (cf. 11,25-26) e juntos vão a Jerusalém realizar um serviço provavelmente de cunho material (cf. 12,25 com $11,27-30)$.

Lucas provavelmente recolheu de uma tradição antiga a informação sobre a lista de ministros da Igreja de Antioquia: "Havia na Igreja de Antioquia 'profetas e doutores': Barnabé, Simeão, chamado Níger, e Lúcio de Cirene, Manaém, companheiro de infância do tetrarca Herodes, e Saulo" (At 13,1). Diferentemente, portanto, de Jerusalém, a organização ministerial da Igreja de Antioquia era constituída por "profetas e doutores" (prophetai kai didáskaloi), que, pelo que tudo indica, eram carismáticos que exerciam ao mesmo tempo a profecia e a didaskalía (cf. 1Cor 14,6).

Na seqüência, no contexto de uma liturgia, Barnabé e Saulo são escolhidos pelo Espírito e recebem uma imposição das mãos para a missão (cf. 13,2-3), prática certamente já conhecida pela comunidade antioquena. A Igreja carismaticamente os envia em missão, encomenda-os à graça de Deus para esta obra (cf. 14,26), da qual prestarão contas à mesma Igreja em seu retorno (cf. At 14,27).

Com muita probabilidade, a comunidade de Antioquia deu o título de "apóstolos" a Barnabé e Saulo no sentido de "missionários" enviados pela Igreja (cf. 2Cor 8,23). Com efeito, Lucas, que se esmera em reservar o título de apóstolos aos Doze, o aplica a Barnabé e Paulo só 
em At 14,4.14, registrando com absoluta fidelidade o que encontrou numa fonte provavelmente antioquena ${ }^{44}$ !

\subsubsection{As missões de Paulo e colaboradores}

As missões de Paulo e de seus colaboradores ocupam mais da metade dos Atos dos Apóstolos.

Embora Paulo reivindique em suas Cartas o título de apóstolos ${ }^{45}$ o historiador sagrado Lucas não lhe dá este título (exceto em At 14,4.14), reservando-o para os Doze, que foram testemunhas de toda a existência histórica de Jesus (cf. At 1,21-22); dá-lhe, todavia, o título de "testemunha" $(22,15 ; 26,16$; cf. ainda 18,$5 ; 20,21.24 ; 22,18 ; 23,11 ; 26,22$; 28,23 ) como aos Doze (cf. 1,$8 ; 2,32 ; 3,15 ; 5,32 ; 10,39-42 ; 13,31$ ). Com efeito, também Paulo foi designado para a missão por Jesus ressuscitado $(9,15 ; 22,15 ; 26,17-18$; cf. Lc 24,47-48; At 1,8). Embora, na Carta aos Gálatas, Paulo insista que nem seu apostolado nem seu Evangelho provêm dos homens (cf. Gl 1,1.11-12.15-17), Lucas documenta a mediação de várias pessoas na origem de sua missão (Ananias: 9,6.10-17; 22,10.12-16; Barnabé: 9,26-30; 11,25-26), ressaltando, assim, o papel da Igreja, dos fiéis e dos responsáveis no princípio do seu ministério.

O ministério de Paulo, segundo Lucas, é essencialmente a pregação da palavra - corroborada por sinais e prodígios - que tem como fruto o surgimento de Igrejas na Pisídia, na Licaônia, na Macedônia, na Acaia e na Ásia.

De acordo com Lucas, Paulo tem viva preocupação com a unidade da Igreja e da missão. Os Atos narram as várias idas de Paulo a Jerusalém $(9,26-29 ; 11,30 ; 12,25 ; 15,1-30 ; 18,22 ; 19,21 ; 20,22-23 ; 21,1-26)$, dão grande importância ao acordo de Jerusalém (15,1-35; cf. Gl 2,1-10), mencionam de passagem a coleta em favor de Jerusalém $(24,17)$. Neste sentido, Lucas confirma o que Paulo escreve aos Gálatas: "Subi até lá em conseqüência de uma revelação e expus-lhes o Evangelho que prego entre os pagãos; eu o expus também, numa conversa particular, às pessoas mais consideradas, por receio de estar correndo, ou ter corrido, em vão" (Gl 2,2).

Lucas conhece vários colaboradores de Paulo - Barnabé, João Marcos, Silas ou Silvano, Timóteo de Listra, Apolo, Priscila e Áquila,

${ }^{4}$ Cf. R. SCHNACKENBURG, "Apostles before and during Paul's time", Op. cit, p. 294; A. LEMAIRE, Les ministères ..., Op. cit, pp. 61.140.180; A. GEORGE, Op. cit, p. 208. ${ }^{45} \mathrm{Cf}$. Nas saudações de 1Cor, 2Cor, Gl, Rm, Cl e Ef, bem como em 1 Ts 2,7; 1 Cor 4,9; 9,12; 15,9; 2Cor 12,12; Rm 11,13; cf. ainda 1 Cor 9,2; Rm 1,5. Paulo tem também consciência de que havia outros apóstolos antes dele (Gl 1,17); cf. V. FUSCO, Le prime comunità cristiane. Tradizioni e tendenze nel cristianesimo delle origini, Bologna, 1997, pp. 263s. 
Erasto - mas em relação a eles não usa nenhum nome que indique determinada função, detendo-se muito pouco em suas atividades.

Diferentemente das Cartas Paulinas, que deixam entrever a existência de um grande número de ministros ${ }^{46}$, Lucas se refere apenas duas vezes aos ministros locais das Igrejas fundadas por Paulo: os "presbíteros" das Igrejas da Licaônia e Pisídia $(14,23)$ e os "presbíteros" da Igreja de Éfeso (20,17-38).

Como entender esta informação, uma vez que Paulo nunca menciona "presbíteros" em suas Cartas e nunca descreve a instituição de ministros locais? Temos várias explicações: (a) Muitos comentadores consideram At 14,23 um anacronismo de Lucas, que projeta no passado as estruturas do seu tempo $0^{47}$. (b) E. Schweizer afirma que "a menção quase casual de detentores de particulares ofícios na comunidade e a falta de títulos determinados mostra que o ordenamento destas formas de serviço não é fundamental para a comunidade lucana. Ela pode por isso assumir formas muito diversas (...) Para Lucas não é essencial indicar as origens de um ofício constitucionalmente necessário à comunidade, mas apresentar uma comunidade aberta a deixarse indicar caminhos novos e não habituais e a abraçá-los" ${ }^{\prime \prime 8}$. (c) Outros julgam possível que as comunidades de Icônio e Antioquia da Pisídia - surgidas junto às sinagogas - tenham adotado uma estrutura "presbiteral"19.

Seja como for, "é natural que, ao deixar as Igrejas que tinham fundado, os missionários se preocupassem com seu ulterior funcionamento e as provessem de responsáveis. Lucas, com uma palavra (cheirotonésantes), nos diz que estes foram designados por Paulo e

to Proistamenoi (1Ts 5,12); episkopoi (Fl 1,1); diákonoi (Fl 1,1; Rm 16,1); prophétai (1Cor $12,10.28 ; 13,2.8 ; 14,1-5.29-33 ; \operatorname{Rm} 12,6$; ainda Ef 3,$5 ; 4,11$ ); didáskaloi (1Cor 12,28-29; 14,26; Rm 12,7; ainda Ef 4,11); kybernéseis (1Cor 12,28); ainda euaggelístai (Ef 4,11) e poiménes (Ef 4,11). "Nem todos estes apelativos são títulos de uma função determinada: "guias" e "pastores" são metáforas, talvez também o seja nestes tempos antigos "epíscopos"; "servidor" (diákonos) tem em Paulo usos diferentes que não é possível atribuir-lhe um sentido muito preciso; a "presidência" pode ser exercida por ministros diferentes. O certo é que os membros das Igrejas paulinas assumem claramente funções numerosas e diversas. Lucas nos proporciona muito poucos dados neste ponto, o que nos prova que a questão dos ministérios não lhe interessa muito" (A. GEORGE, Op. cit, p. 213).

${ }_{47}$ Cf. H. CONZELMANN, Die Apostelgeschichte = HNT, 7, Tübingen, 1963; E. HAENCHEN, Die Apostelgeschichte, Göttingen, 1968, 6a ed.; E. SCHWEIZER, Op. cit, p. 58, nota 271; R. SCHNACKENBURG, "Lukas als Zeuge verschiedener Gemeindestrukturen", Op. cit, p. 243.

${ }^{48}$ E. SCHWEIZER, Op. cit, p. 59.

${ }^{49}$ Cf. G. STÄHLIN, Die Apostelgeschichte = NTD, 5, Göttingen, 1962; H. SCHÜRMANN, Das Testament des Paulus für die Kirche, Düsseldorf, 1962; Traditionsgeschichtliche zu den synoptischen Evangelien, Düsseldorf, 1968, p. 331. 
Barnabé", sem, evidentemente, excluir a atuação do Espírito Santo (cf. 6,$3 ; 13,2 ; 20,28$ ) e a participação da assembléia (cf. 1,$23 ; 6,3-5 ; 13,3$ ). Além disso, sabendo da existência de presbíteros em Jerusalém, "ao referir a presença de presbíteros nas comunidades paulinas, talvez queira sublinhar a identidade de estrutura nas diversas Igrejas" ${ }^{\prime 50}$.

O "testamento de Mileto" aos "presbíteros" de Éfeso (At 20,17-35) contém a única exposição clara do ministério dos responsáveis pelas Igrejas locais no livro dos Atos (vv. 28-32). Neste texto, (a) os presbíteros (cf. 20,17) são chamados de epískopoi (cf. 20,28); (b) o termo é usado no plural, como o fizera Paulo em Fl 1,1, diferentemente, porém, de $1 \mathrm{Tm} 3,2$, que o usa no singular; (c) afirma que foram constituídos tais pelo Espírito Santo; (d) sua função é pastoral: "cuidar do rebanho" e "apascentar a Igreja de Deus" (cf. também vv. 29-31).

Finalmente, "é digno de nota que Lucas somente coloca nos lábios de Paulo os termos paulinos episkopoi (Fl 1,1) e poimáinein (1Cor 9,7; cf. Ef 4,11), nunca o de 'anciãos'. Parece conhecer, portanto, que Paulo não empregou este título: todavia, tem interesse em usá-lo em 20,17 e em 14,23. No momento em que Paulo vai desaparecer, Lucas provavelmente quer indicar desta maneira os que vão apascentar a Igreja de Deus e lhes dá o mesmo título daqueles que agora estão com Tiago à frente da Igreja de Jerusalém (cf. 21,18). Provavelmente move-o a isto a situação da Igreja no momento em que escreve, talvez também seu interesse de historiador pelos portadores da tradição (cf. 21,16). Realça, deste modo, a unidade da Igreja, que se funda na continuidade entre a geração das primeiras testemunhas e os ministros de seu tem$\mathrm{po}^{\prime \prime 51}$.

\subsection{A primeira Carta de Pedro}

A primeira Carta de Pedro nos oferece um eco fiel da catequese primitiva. Destinada às comunidades da Ásia Menor, onde predominam os convertidos de origem pagã, mas as tradições judeu-cristãs permanecem vivas, ela recolhe uma variedade de elementos muito valiosos: confissões de fé, hinos, fórmulas catequéticas, código de obrigações domésticas, etc.

A Igreja edificada sobre Cristo aparece como povo escolhido e comunidade sacerdotal. $\mathrm{O}$ conhecido texto de $1 \mathrm{Pd}$ 2,4-10 não se refere aos ministérios, nem ao culto litúrgico-ritual em sentido estrito, nem às relações entre os membros da comunidade eclesial, mas ao caráter

\footnotetext{
${ }^{50}$ A. GEORGE, Op. cit, p. 213.

${ }^{51}$ Idem, p. 215
} 
coletivamente sacerdotal do Povo de Deus - por sua participação graciosa no sacerdócio existencial de Cristo - cabendo-lhe, portanto, apresentar a Deus ofertas espirituais, que consistem na entrega da própria vida a Deus e aos irmãos (cf. Rm 12,1) (22 $^{52}$

Os capítulos 4 e 5 oferecem notícias interessantes sobre a vida comunitária. Merecem destaque os seguintes conselhos: "Ponde-vos, cada um conforme o dom (chárisma) recebido, a serviço uns dos outros, como bons administradores da multiforme graça de Deus" $(4,10)$. E na sequiência: "Se alguém fala (lalei), faça-o para transmitir as palavras de Deus; se alguém presta um serviço (diakonei), faça-o com a força que Deus concede" $(4,11)$. Se o v. 10 insiste na origem carismática do ministério ${ }^{53}$ o v. 11 destaca o ministério da palavra (que podia tomar diversas formas) e os diversos serviços comunitários (cf. 5,1-4).

A primeira Carta de Pedro contém uma exortação aos "presbíteros" (cf. 5,1-4) ${ }^{54}$, não tanto para definir o lugar desses na comunidade, quanto para indicar o espírito com que devem exercer sua função.

O autor apresenta-se como "co-presbítero" (sympresbyteros), sublinhando, desta forma, de um lado, a responsabilidade comum a ele e aos "presbíteros", de outro, o direito que tem de intervir (cf. 5,1).

Segundo alguns, os versículos seguintes $(5,2-4)$ seriam citação de um documento anterior, de extração semítica, talvez de origem essênica ${ }^{55}$. Na verdade, a crítica se inclina cada vez mais a relacionar o epískopos cristão com o mebaqqer do Documento de Damasco ${ }^{56}$, como veremos.

\footnotetext{
${ }^{52}$ Cf. A. VANHOYE, Sacerdotes antiguos, sacerdote nuevo según el Nuevo Testamento, Salamanca, 1984, pp. 251-274; CNBB, Missão e ministérios dos cristãos leigos e leigas, São Paulo, 1999, no 73 e 74

53 Carismas são "todos os dons particulares da graça de Deus, os dotes pessoais, os 'talentos' que a generosidade de Deus entrega a cada um para que sirva com eles à comunidade" (M.-A. CHEVALLIER, Esprit de Diell, paroles d'hommes, Neuchâtel, 1966, p. 146).

${ }^{54}$ "Não deixa de ter alcance histórico a constatação de que os presbíteros ocupam nestas Igrejas da Ásia Menor um lugar de destaque. Essas comunidades procedentes sobretudo do paganismo, receberam algumas formas de expressar sua fé marcadas com um selo especial por suas origens palestinenses e, do mesmo modo, adotaram a estruturação das comunidades judeu-cristãs" (E. COTHENET, "La primeira epistola de Pedro - La epistola de Santiago", in J. DELORME (org.), El ministerio ..., Op. cit, p. 140).

${ }^{55}$ Cf. W. NAUCK, "Probleme des frühchristlichen Amtsverständnisses", Zeitschrift für die neutestamentliche Wissenschaft 48 (1957) 200-220.

${ }^{56}$ Cf. J. COLSON, Les fonctions ecclésiales aux deux premiers siècles, 1956, pp. 110ss.; E. COTHENET, Op. cit, p. 141; R. E. BROWN, Sacerdote e bispo: reflexões biblicas, São Paulo, pp. 68-70; E. CATTANEO, Op. cit, pp. 57-62.
} 
Os "presbíteros" são, antes de tudo, apresentados como "pastores": "apascentai (poimánate) o rebanho de Deus que vos é confiado" (5,2; cf. Ef 4,11). A imagem do pastor indica a autoridade daquele que tem a tarefa de reunir o rebanho, assegurar sua coesão e, assim, protegêlo dos perigos. Para a primeira Carta de Pedro, Cristo é o príncipe dos pastores (archipóimen: 5,4): a autoridade dos "presbíteros" só pode ser exercida em dependência e por delegação do "pastor" do rebanho, Cristo (1Pd 2,25; cf. Mt 9,36; 26,31 par.; Lc 15,3-7 par.; Jo 10; Jo 21).

Sua função é "velar" (episkopountes) pelo rebanho, como lembra também o livro dos Atos: "Cuidai de vós mesmos e de todo o rebanho de cuja guarda o Espírito Santo vos constituiu 'epíscopos'; apascentai (poimainein) a Igreja de Deus que ele adquiriu para si com o seu próprio sangue" (At 20,28). Os responsáveis pela Igreja devem manter a vida e a unidade do rebanho. É importante observar que aqui, como em $\mathrm{Tt}$ 1,5.7, há uma equivalência entre "presbíteros" e "epíscopos"57.

\subsection{A Carta de Tiago}

A Carta de Tiago ${ }^{58}$ só menciona os responsáveis pela comunidade ao falar da assistência aos doentes: "Algum de vós está doente? Mande chamar os "presbíteros" da Igreja e que estes orem, depois de têlo ungido com óleo em nome do Senhor. A oração da fé salvará o paciente: o Senhor o porá de pé e, se tiver pecados, ser-lhe-ão perdoados" (Tg 5,14-15). A existência de "presbíteros" - provavelmente formando um "colégio" - na comunidade local parece, portanto, um fato consolidado.

\subsection{Os Escritos Joaninos}

Todos os comentadores coincidem em afirmar que o quarto Evangelho insiste na relação pessoal que une o discípulo com Jesus Cristo, mas diferem muito quanto à sua eclesiologia e, neste contexto, quanto à sua concepção dos ministérios.

Um dos maiores especialistas em João sintetiza de modo muito eficaz a eclesiologia do quarto Evangelho - "uma comunidade de povo

\footnotetext{
57 "Estamos, pois, nestes tempos antigos nos quais a direção da comunidade se exerce de forma colegiada sem aparecer ainda o episcopado monárquico" (E. COTHENET, Op. cit, p. 142).

${ }^{58}$ Escrita em excelente grego, mas contendo alguns semitismos, apesar de citar a LXX, a carta de Tiago deve proceder de um ambiente muito próximo ao judaísmo helenístico; alguns a consideram muito antiga (antes do ano 50, na opinião de J. B. MAYOR), outros, certamente com maior razão, bastante recente (fins do século I).
} 
pessoalmente apegado a Jesus"59 - e a eclesiologia das Epístolas de João - "uma comunidade de indivíduos guiados pelo Espírito Paráclito" ${ }^{\prime \prime 0}$.

Já que o cerne da eclesiologia joanina consiste numa relação pessoal e permanente com Jesus, o doador da vida que desceu de Deus, como se mantém a unidade da comunidade, que, evidentemente, é uma realidade coletiva? Segundo João, três fatores mantêm a comunidade unida: o ensinamento da fé (o fator decisivo da unidade dos discípulos é a comunhão, na fé, com a palavra de Jesus vivificada pelo Espírito); a vida sacramental (a comunidade eclesial só pode viver liturgicamente por e em sua relação com o Jesus do passado, o qual com suas palavras e obras deu para sempre o sentido de toda vida sacramental) e, sobretudo, a relação pessoal de cada ovelha com o único Pastor (a comunidade só se unifica na unidade que liga Jesus com seu Pai - cf. Jo 17,21; longe de dissolver-se por um aparente "individualismo", a relação pessoal do discípulo com Cristo alimenta o amor, que é a única realidade que dá consistência à Igreja ${ }^{61}$.

Mas como manter a unidade misteriosamente fundada em Jesus sem destruir a diversidade necessária numa comunidade?

Antes de tudo, e sobretudo, há um "ministério" fundamental comum a todos: o serviço mútuo que nasce da fé em Jesus e que vai até o sacrifício de si mesmo: serviço da palavra (cf. Jo 15,27; 16,14-15; 17,8.20) e do amor sem limites (cf. Jo 13,15-16).

Além disso, não se pode não reconhecer que João atesta a existência de determinados atos ministeriais (e de ministros) - o batismo, o fato de João escrever a primeira Carta, a existência de "missionários itinerantes", o presbítero autor da terceira Carta e as figuras de Gaio e Diótrefes mencionados na terceira Carta - e distingue algumas funções no grupo dos discípulos.

João, seguindo a tradição comum, distingue entre os 'discípulos' e os 'Doze' que Jesus "escolheu" (Jo 6,70) e aos quais se dirige (cf. 6,67), e eles, diferentemente de outros discípulos, continuam com ele (cf. $6,68 \mathrm{com} 6,66$ ). Do mesmo modo, se os nomes citados na última ceia se encontram na lista clássica dos apóstolos, é que são "os que Jesus escolheu" $(13,18)$, expressão que designava os Doze (cf. 6,70). Ou seja: João conhece a existência dos Doze e lhes confere um lugar à parte:

${ }^{59}$ R. E. BROWN, As Igrejas dos Apóstolos, São Paulo, 1986, pp. $106 \mathrm{~s}$

${ }^{60}$ Idem, pp. 128s.; cf. The Gospel according to John, N. York, 1966; A comunidade do discípulo amado, São Paulo, 1984.

${ }^{61}$ Cf. X. LÉON-DUFOUR, "El Evangelio y las epístolas joánicas", in J. DELORME (org.), El ministerio ..., Op. cit, pp. 229-235. . 
constituem historicamente o grupo fundador, o dos primeiros discípulos reunidos por Jesus (cf. 1,35-50; 6,70; 13,18; 15,16; 17,18; 20,21; 21,111). As palavras do discurso durante a ceia lhes são perfeitamente adequadas (cf. 15,16; 15,27; 17,9.12.20).

Apesar destes traços diferenciadores dos Doze, ordinariamente eles são assimilados aos demais discípulos: para João, "grupo fundador e comunidade dos discípulos são diferentes só no tempo (o de Jesus, o da Igreja) porque, cada um a seu modo, ambos constituem a Igreja. Por este motivo a fórmula de eleição ("os que eu escolhi": 15,16), que

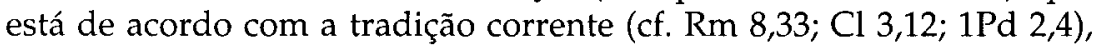
o dever de produzir fruto e de comunicar a palavra $(15,8)$, tudo isso convém aos discípulos em geral da mesma forma que aos primeiros apóstolos. E a "consagração" pedida em 17,19 se dirige a todo o corpo da Igreja, prefigurado nos Doze aqui também conforme a tradição comum do "povo sacerdotal" $(1 \mathrm{Pd} 2,9)^{\prime \prime 62}$.

Também como na tradição comum, Pedro ocupa um lugar especial no grupo dos discípulos. No capítulo 21, recebe a missão de apascentar as ovelhas de Jesus. Sendo que a pesca milagrosa equivale à ordem de fazer discípulos de Cristo, pode-se pensar que Pedro recebe o encargo de apascentar os novos discípulos do rebanho (21,1-14), o que é explicitado no diálogo entre Jesus e Pedro (21,15-23). Pedro possui uma autoridade superior à dos outros apóstolos? Segundo o texto, Pedro propriamente tem autoridade não sobre os pescadores (os missionários/os apóstolos), mas sobre os peixes, que, metaforicamente, são as ovelhas do rebanho (os crentes). Ocupa, sim, um lugar diferente, mas porque é chamado a amar mais a Jesus, permanecendo-lhe fiel. Sua autoridade advém somente da missão recebida do Ressuscitado, ligada à medida do amor que lhe é exigido. E Pedro deve apascentar não as suas ovelhas (ou o seu rebanho), mas as ovelhas de Jesus: "apascenta as minhas ovelhas"!

Embora Pedro ocupe um lugar particular, o "discípulo amado" como que lhe faz de contraponto. Não é possivel afirmar que pertencesse ao grupo dos Doze "o outro discípulo" (Jo 18,15-16; 20,3-4.8) ou - equivalentemente (cf. 20,2) - "o discípulo que Jesus amava" $(13,23-$ $26 ; 19,25-27 ; 20,2 ; 21,7 ; 21,20-23 ; 21,24)$. Interpretado das mais diversas maneiras ${ }^{63}$, certamente não se trata de um mero símbolo, mas de um personagem histórico dotado de uma importância simbólica inquestionável.

\footnotetext{
62 Idem, p. 238.

${ }^{63} \mathrm{O}$ discípulo perfeito (Loisy), o cristão de origem grega (Bultmann), a função profética na Igreja (Kragerud), etc.
} 
O que chama a atenção no evangelho de João é a justaposição entre o discípulo amado e Pedro, marcando o contraste entre os dois personagens: Pedro recorre ao discípulo para saber quem é o traidor $(13,23-$ 28); Pedro é introduzido pelo discípulo no palácio do Sumo Sacerdote $(18,15-16)$; Pedro desaparece depois da tríplice negação, mas o discípulo é o único que está ao pé da cruz $(19,25-26)$; o discípulo tem uma relação especial com a Mãe de Jesus (19,25-26); o discípulo é a testemunha privilegiada da morte redentora de Jesus (19,35); o discípulo corre mais rápido que Pedro na ida ao sepulcro $(20,4)$; só o discípulo viu e acreditou $(20,8)$; o discípulo diz a Pedro que é o Senhor ressuscitado na aparição junto ao lago $(21,7)$; Pedro se preocupa com o futuro do discípulo, e Jesus anuncia a morte de Pedro e a sobrevivência do discípulo (21,21-23); o discípulo é, finalmente, a testemunha que garante para sempre a verdade do Evangelho $(21,24)$.

Ainda que os dois contrastem - à fragilidade e falta de compreensão de Pedro opõem-se a perspicácia da visão e a designação excepcional do discípulo "que Jesus amava" - não se pode dizer que João tenha querido rebaixar Pedro. Afinal, relata sua vocação especial e sua mudança de nome (cf. 1,42), sua declaração de adesão incondicional a Jesus (cf. 6,6869) e a função pastoral única que recebeu de Jesus mesmo depois de têlo negado três vezes (cf. 21,15-17). Pedro, porém, morrerá (cf. 21,18-19), enquanto o outro discípulo "permanecerá" até que Ele volte (cf. 21,22). Várias hipóteses foram levantadas para explicar esta sorte diversa ${ }^{64}$.

Na verdade, "junto a Pedro, cujo primado João não discute, o discípulo manifesta ao leitor do Evangelho que existe "outra" maneira de ser discípulo, que é a de ser especialmente amado por Jesus e que é a que revela o segredo da palavra de Jesus". Não só: "Se é verdade que por detrás do ministério de Pedro se pode considerar o ministério pastoral em geral, poder-se-ia também afirmar que, na estrutura da Igreja, junto ao ministério pastoral encarnado em Pedro, está a função do discípulo por excelência que atesta a verdade do Evangelho e a presença de Jesus de Nazaré. Conceder um valor típico a Pedro é conceder outro também ao discípulo amado, é apresentar uma "função" diferente da supremacia pastoral: a do discípulo capaz de ver, compreender e falar, porque se sabe amado por Jesus" ${ }^{\prime 65}$. Numa leitura

\footnotetext{
${ }^{64}$ A função de Pedro acabaria com sua morte (cf. O. CULLMANN, "San Pietro. Discepolo-Apostolo-Martire", in AA.VV., Il primato di Pietro, Bologna, 1965); ou, pelo contrário, assim como Jesus comunicou seu ofício pastoral a Pedro depois de sua morte, da mesma forma a função de Pedro passaria a outros depois de ele morrer (cf. P. BENOIT, Passion et résurrection du Seigneur, 1966, pp. 344-349); diferentes Igrejas buscavam em Pedro e no outro discípulo diferentes "patronatos", sem pretender fundamentar a preeminência de Pedro; ou então, o que "permanece" depois da morte dos dois personagens é o Evangelho do discípulo amado (cf. P. BONNARD, Foi et vie 8 (1970) 58-59), etc.

${ }_{65} \mathrm{X}$. LÉON-DUFOUR, Op. cit, p. 243
} 
mais profunda do quarto Evangelho, dever-se-ia considerar "quão importante é o discipulado, e não os ofícios ou carismas, nem outras distinções" ${ }^{\prime 66}$, pois, mais do que pelos diversos carismas que distinguem entre si os cristãos, João "está interessado em um status básico em que a vida é recebida por todos" ${ }^{\prime \prime 6}$.

\subsection{O Apocalipse}

O Apocalipse utiliza a palavra "diaconia" (com o sentido de exercício concreto da caridade) uma única vez (cf. Ap 2,19). Contém, sim, múltiplas alusões à vida litúrgica das comunidades, polarizadas entre a ação de graças a Deus que convoca os fiéis a compartilharem da realeza de Cristo e o testemunho corajoso que chega até o martírio.

Suas informações sobre ministérios são escassas: algumas alusões "aos apóstolos, aos profetas" (cf. 18,20.24) e "aos anjos das Igrejas".

O dado mais importante é, certamente, a descrição da Jerusalém celeste, ponto de chegada da difícil peregrinação da Igreja. A Jerusalém celeste, ao mesmo tempo, templo e esposa, tem por fundamento os "doze apóstolos" do Cordeiro: "As muralhas da cidade tinham doze fundamentos, e sobre eles os doze nomes dos doze apóstolos do Cordeiro" $(21,14)$. Aqui, a imagem dos apóstolos-fundamento - que é tradicional (cf. Mt 16,18; Gl 2,9; cf. também Mt 19,28; Lc 22,30) - está associada à representação da comunidade eclesial como templo escatológico. Como Ef 2,20, este texto do Apocalipse sublinha o caráter colegial e definitivo da função apostólica: a Igreja repousa sobre o testemunho que os doze tributam ao Cordeiro, e sua estabilidade e irradiação missionária (cf. 21,14) dependem da fidelidade a este testemunho.

$\mathrm{O}$ autor do Apocalipse apresenta-se como "profeta" (cf. 22,9) e reivindica uma autoridade absoluta para sua mensagem (cf. 22,7.10.1819), autoridade que procede diretamente de Cristo e o situa diante da comunidade. João não está sozinho em seu ministério profético: "Estas palavras são certas e verídicas; o Senhor, o Deus dos espíritos dos 'profetas, enviou seu anjo para mostrar a seus servos o que deve acontecer em breve (...) Sou - declara o anjo revelador - um companheiro de serviço, teu e dos teus irmãos, os 'profetas', e dos que guardam as palavras deste livro" (22,6.9; cf. 10,7 com Rm 1,2 ou com Ef 3,3.5). Ademais, todos podem ser chamados a dar a Jesus o testemunho até o derramamento do sangue e, neste sentido, exercer um serviço "profético" na vida da Igreja (cf. Ap 11, especialmente 11,18).

${ }^{66}$ R. E. BROWN, Op. cit, p. 118.

${ }^{67}$ Idem, p. 114. 
Os "anjos das Igrejas" receberam as mais diversas interpretações: anjos mesmo (cf. Dn 10,13); personificações das Igrejas; dirigentes da comunidade. Se se levar em conta o contexto histórico, sabe-se que as Cartas às sete Igrejas destinam-se a comunidades atestadas por Inácio de Antioquia no início do século II, quando cada Igreja - segundo o testemunho que seria isolado de Inácio ${ }^{68}$ - é dirigida por um bispo monárquico rodeado por um colégio de presbíteros e alguns diáconos. Pouco tempo antes do Apocalipse, o livro dos Atos dos Apóstolos atesta a presença em Éfeso de um grupo de "presbíteros-epíscopos" (cf. At 20). Por isso, não seria fora de propósito pensar que "apesar da diferença de gênero literário, o Apocalipse se inscreve, pois, num desenvolvimento histórico que dará à pessoa do episkopos um papel cada vez mais importante na Igreja"69, ainda que as Cartas às sete Igrejas não nos permitam precisar o papel do chefe da comunidade local.

Na mesma linha, há quem interprete o coro dos "vinte quatro anciãos" vestidos de branco e coroados de ouro (cf. Ap 4-5, especialmente 4,4$)$ - que corresponderiam às vinte quatro classes sacerdotais de Israel (cf. $1 \mathrm{Cr} 24,1-19$ ) - como sendo o grupo dos presbíteros sentados em torno o bispo, que presidia a Eucaristia ${ }^{70}$, hipótese que merece ser analisada, uma vez que Inácio de Antioquia apresenta os presbíteros exatamente como "uma preciosa coroa espiritual" em torno do bispo ${ }^{71}$.

\section{Diversidade e evolução dos ministérios do Novo Testamento}

Tendo em conta os dados levantados na seção anterior, procuraremos agora compreender a diversidade e a evolução dos ministérios no arco de tempo compreendido pelo Novo Testamento, situando-os, portanto, em seu contexto eclesial e histórico. O panorama histórico que vamos tentar reconstituir em suas linhas essenciais abrange quatro etapas principais: a) o ministério de Jesus (cerca de 27-30); b) a comunidade primitiva de Jerusalém (aproximadamente 30-43); c) a época apostólica (cerca de 43-65); d) a época dos "evangelistas" $e$ pastores (cerca de 65-100).

3.1. Além de dirigir-se à totalidade do povo "Israel", Jesus, pouco a pouco, vai formando ao redor de si um grupo de "discípulos", den-

${ }^{68}$ Cf. J. I. GONZÁLEZ FAUS, "Ningún obispo impuesto" (San Celestino, papa), Las elecciones episcopales en la historia de la Iglesia, Santander, 1992, p. 21.

${ }^{69}$ E. COTHENET, "El Apocalipsis", in J. Delorme (org.), El ministerio ..., Op. cit, p. 256.

${ }^{70}$ Cf. J. COLSON, Ministre de Jésus-Christ ou le sacerdoce de l'Évangile, Paris, 1966, pp. $199-203$

${ }^{1}$ Cf. INÁCIO DE ANTIOQUIA, Magn. XIII,1. 
tre os quais ele instituiu - ainda na fase galilaica de seu ministério os "Doze" com um significado e uma missão especiais. A expressão "os Doze" pertence ao substrato mais antigo dos Evangelhos. Mas, historicamente falando, os Doze não são "apóstolos". O significado deste grupo era claro no horizonte de compreensão judaico: Jesus escolheu um grupo de Doze para simbolizarem as doze tribos de Israel e serem seus chefes no Israel renovado: "... vos sentareis em doze tronos para julgar as doze tribos de Israel." (Mt 19,28; cf. Lc 22,28-30). Julgar, na linguagem bíblica, é decidir, administrar, exercer a função de chefe: quando Jesus for proclamado rei messiânico, os Doze serão seus "ministros" (cf. Mc 10,35-40). Certamente, desde o tempo do ministério galileu, Jesus começou a prepará-los para assumir sua responsabilidade futura (cf. Mc 3,14; 6,7; Mt 10,6; ver também Mc 6,30). Sobretudo depois da crise da Galiléia, Jesus dá uma atenção particular aos discípulos ${ }^{72}$. No grupo dos Doze, Simão, denominado Kéfas = Pedra / Pedro, pelo próprio Jesus (cf. Mt 16,17-19), é certamente o líder (cf. Mc 8,29.32; 14,66-72; Lc 24,34; 1Cor 15,5; cf. Lc 22,32).

3.2. Os "retratos ideais" da comunidade de Jerusalém (cf. At 2,44$47 ; 4,32-35)$ não impedem Lucas de relatar as dificuldades - internas e externas - que a comunidade teve de enfrentar. Um dos problemas foi certamente o dos ministérios: primeiro, a recomposição do grupo dos Doze, comprometido em seu simbolismo pela traição de Judas, o que se faz pela escolha de Matias, que preenche as exigências de "discípulo histórico" de Jesus e de testemunha da ressurreição (cf. At 1,21-22); a criação do grupo dos Sete, cujo líder é Estêvão, para assegurar o ministério da comunidade dos helenistas: "já que existem dois grupos culturais diferentes, é preferível que cada grupo se organize em comunidades autônomas com seus próprios ministros...face a uma nova necessidade da Igreja, os Doze não hesitam em criar uma nova estrutura ministerial e não se sentem limitados pelo fato de que Jesus havia instituído só o ministério dos Doze"73. Com a dispersão da comunidade cristã dos helenistas, provocada pela perseguição dos judeus helenistas, o grupo dos Sete deixa de, existir enquanto grupo constituído; alguns deles, como Felipe, passam a anunciar o Evangelho nas regiōes da Judéia e da Samaria (cf. At 8,1ss.). A mesma sorte tocará, não muito tempo depois, ao grupo dos Doze, devido, por um lado, à perseguição de Herodes (cf. At 12,1ss.) e, por outro, à entrada dos primeiros convertidos pagãos na Igreja (cf. At 10-11). Diante desta nova circunstância, "a estrutura ministerial dos Doze - que se referia ao Israel das doze tribos - perde, pois, sua razão de ser e, como por

72 Cf. R. FABRIS, Op. cit, pp. 133ss.; 221ss.; A. G. RUBIO, O encontro com Jesus Cristo vivo, São Paulo, 1994, pp. 74ss; P. CODA, Dio tra gli uomini. Breve cristologia, Casale Monferrato, 1991, pp. 95-96.

${ }^{73}$ A. LEMAIRE, Os ministérios na Igreja, São Paulo, 1977, p. 17. 
ocasião da instituição dos Sete, a extensão do Evangelho a um novo grupo humano conduzirá à criação de novos ministérios"774.

3.3. À medida que, deixando os limites da Palestina, a missão cristã avança entre os pagãos, é preciso organizar o serviço missionário dos "apóstolos", palavra grega que significa exatamente 'missionários', 'enviados'. O primeiro grande centro de irradiação missionária do Evangelho foi, certamente, a comunidade cristã de Antioquia da Síria: foi aí que, pela primeira vez, a Boa Nova foi anunciada aos gregos (cf. At 11,20) e os discípulos receberam o nome de 'cristãos' (cf. At 11,26). Esta comunidade, animada por "profetas e doutores" (cf. At 13,1), resolveu, inspirada pelo Espírito Santo, enviar dois de seus membros - Barnabé e Paulo - como "apóstolos" a Chipre e às cidades do sul da Ásia Menor (cf. At 13,1-3). Paulo ficará conhecido na tradição cristã como o Apóstolo por antonomásia. E quando evoca a organização dos ministérios na Igreja, começa a lista com os ministros que conheceu em Antioquia: "Os que Deus dispôs na Igreja são, primeiro apóstolos, segundo profetas, terceiro doutores" (1Cor 12,28). A criação destes três ministérios especializados pode explicar a irradiação extraordinária da Igreja de Antioquia no primeiro século. Nem todas as comunidades, porém, estão organizadas de acordo com este modelo; os escritos desta época testemunham que, em outras comunidades, existiam outros tipos de ministérios ${ }^{75}$. Depois da perseguição dos helenistas, a comunidade cristã, em Jerusalém, é essencialmente constituída por "hebreus", e se organizou inspirada no modelo tradicional das comunidades judaicas: além de contar com profetas (cf. At 11,27), esta comunidade é presidida por "presbíteros" (anciãos) (cf. At 11,29-30; 15,2.4.6. etc.; 16,$4 ; 21,18)$. Também as comunidades judeu-cristãs da Cilícia e do sul da Ásia Menor seguem este modelo (cf. At 14,23; 15,22). Na Igreja de Tessalônica, existem aqueles que se afadigam, que a presidem e exortam (cf. 1Ts 5,12-13). A vizinha Igreja de Filipos é, na mesma época, dirigida, por epískopos e diákonos (cf. Fl 1,1). A impressão que se tem é que, nesta época, as comunidades que surgem graças a um trabalho evangelizador intenso e inteligente organizamse de acordo com suas próprias tradições.

3.4. À expansão missionária segue-se a consolidação eclesial. Após o desaparecimento das testemunhas diretas da vida e/ou da ressurreição de Jesus, os responsáveis pela Igreja vão concentrar suas atenções na fidelidade ao ensinamento do Mestre e à unidade da Igreja. A Carta aos Efésios já assinala esta transição da época "apostólica" para a época dos "evangelistas e pastores" (Ef 4,11). Multiplicam-se as recomendações aos responsáveis pelas comunidades locais: "Cuidai de vós mesmos e de todo o rebanho de cuja guarda o Espírito Santo vos

\footnotetext{
${ }^{74}$ Idem, p. 18

${ }^{75} \mathrm{Cf}$., neste trabalho, a seção relativa às cartas paulinas.
} 
constituiu epískopos; apascentai a Igreja de Deus que ele adquiriu para si com o seu próprio sangue" (At 20,28). "Apascentai o rebanho de Deus que vos foi confiado..." (1Pd 5,2-3). Severas advertências deixam entrever que as comunidades deste período já experimentaram a conduta indigna de alguns líderes e os discursos insensatos de certos pregadores (cf. At 20,29-31; Tt 1,10-16). É neste contexto que são compostas as epístolas justamente chamadas de "pastorais". As comunidades cristãs precisam organizar-se: "Se eu te deixei em Creta, foi para que ali concluas a organização e estabeleças 'presbíteros' em cada cidade, de acordo com minhas instruções" (Tt 1,5). Os "presbíterosepíscopos" assumem a presidência de cada comunidade: "Os anciãos que exercem a presidência merecem ser duplamente honrados, sobretudo, aqueles que se afadigam no ministério da palavra e no ensino" $(1 \mathrm{Tm} 5,17)$. Definem-se com clareza os requisitos que os ocupantes deste cargo devem possuir: "O epískopos deve ser irrepreensível..." (1Tm 3,2ss); "Cada um deles (presbíteros) deve ser irrepreensível... Pois é preciso que o epískopos seja irrepreensivel na sua função de ecônomo de Deus..." (Tt 1,6-9). Ao lado dos presbíteros, também chamados de epíscopoi, aparecem também diákonoi: embora suas funções sejam ainda pouco claras, seus portadores devem preencher requisitos precisos, semelhantes aos dos "presbíteros-epíscopos" (1Tm 3,8-13; cf. Fl 1,1). Na Didaqué, aliás - que contém material tradicional muito antigo reelaborado pelo redator final (em torno do ano 100$)^{76}-$ encontramos um texto semelhante: "Assim, pois, escolhei-vos episcopoi e diáconoi dignos do Senhor, homens mansos e desinteressados, verazes e experimentados, pois também eles exercem em vosso favor o ministério (leitourghía) dos profetas e doutores" (Didaqué, XV, 1).

(Continua)

Pe. Antonio José de Almeida obteve o título de mestre em Teologia na Pontifícia Universidade Gregoriana, Roma, em 1984, e de doutor em Teologia pela mesma Universidade, em 1986, com a tese Os ministérios não-ordenados na Igreja da América Latina. É pároco da Catedral de Apucarana - PR, Diretor da Escola de Teologia "Padre Tito Cerasolli" e Professor de Teologia no Centro Interdiocesano de Teologia de Cascavel - PR. Entre outras obras publicou Os ministérios não-ordenados na Igreja latino-americana, Loyola: São Paulo, 1989 e Teologia dos ministérios não-ordenados na América Latina, Loyola: São Paulo, 1989

Endereço: Catedral Nossa Senhora de Lourdes

Praça Rui Barbosa, s/n

86.800-970 Apucarana - PR

c-mail: catedral@net21.com.br

${ }^{76}$ Cf. E. CATTANEO, Op. cit, p. 237. 